\title{
Bee Diversity in Thailand and the Applications of Bee Products
}

\author{
Atsalek Rattanawannee and Chanpen Chanchao \\ Department of Biology, Faculty of Science, Chulalongkorn University, Bangkok, \\ Thailand
}

\section{Introduction}

This chapter provides information on honey bees (genus Apis) and their reasonably close relative group, the stingless bees within the Meliponini Tribe. Their taxonomic position, common morphology and behaviour are defined and explained. Also, a species identification of the four native Thai honey bee species, including the comb and nest structure, worker morphology, species distribution and description of each species behaviour, is summarized. Beyond their role as pollinators, honey bees and stingless bees have important economic, ecological and social values for many rural people in Asia. Especially, wild honey bees are hunted for their products (honey, brood and wax), providing many people with a useful component of household income. Therefore, the applications of bee products, which are important for many rural people in Asia including Thailand, are briefly outlined.

\section{The genus Apis}

Honey bees are classified in the Apini tribe within the subfamily Apinae and family Apidae (Ruttner, 1988). They are part of the large insect order Hymenoptera that includes bees, wasps, ants and sawflies (Gullan \& Cranston, 2000). Apis is the only genus of true honey bees and is comprised of the ten Asian species and one Western species (Oldroyd \& Wongsiri, 2006).

Some of the most discriminate morphological criteria for worker bees of the genus Apis are: the compound eyes covered with erect long hairs, a strongly convex scutellum, the pollen press on the hind leg, the greatly elongated marginal and submarginal cells of the forewing and the jugal lobe in the hind wing (Oldroyd \& Wongsiri, 2006).

All honey bee species are highly social insects. Oldroyd \& Wongsiri (2006) revealed at least three criteria for defining the eusociality form in honey bees that correspond with that of Wilson (1971). First, an individual larva is reared and cared for by a multitude of workers, and no one larva receives special attention compared to the others (of the same caste), except those going to be queens. Second, they have a pronounced reproductive division of labour, which is that one individual monopolizes reproduction (queen) while others are sterile (workers) for most or all of the time. Third, the form of eusociality in honey bees has overlapping generations. Therefore, during the short life span of workers they are surrounded by their sisters and brothers. 
Usually, the social structure of a honey bee colony is composed of a single fertile female queen, several thousand sterile female workers, and, at certain times, a few hundred males (drones) (Fig. 1). The queen and workers both develop from fertilized eggs (diploid, $2 n=32$ ) that are heterozygous at the sex locus. Their different and irreversible development trajectorie are thus not directly genetically predetermined but rather are determined solely epigenetically (environmentally) by their feeding and other treatments that they recieve as larvae. Unlike the queen and workers, drones or functional males are hemizygotes (haploid, $\mathrm{n}=16$ ) and develop from unfertilized eggs under the arrhenotous sex determination system. Note that fertilised eggs that are homozygous at the sex locus will develop as diploid males, but their functionality and fertility is limited.

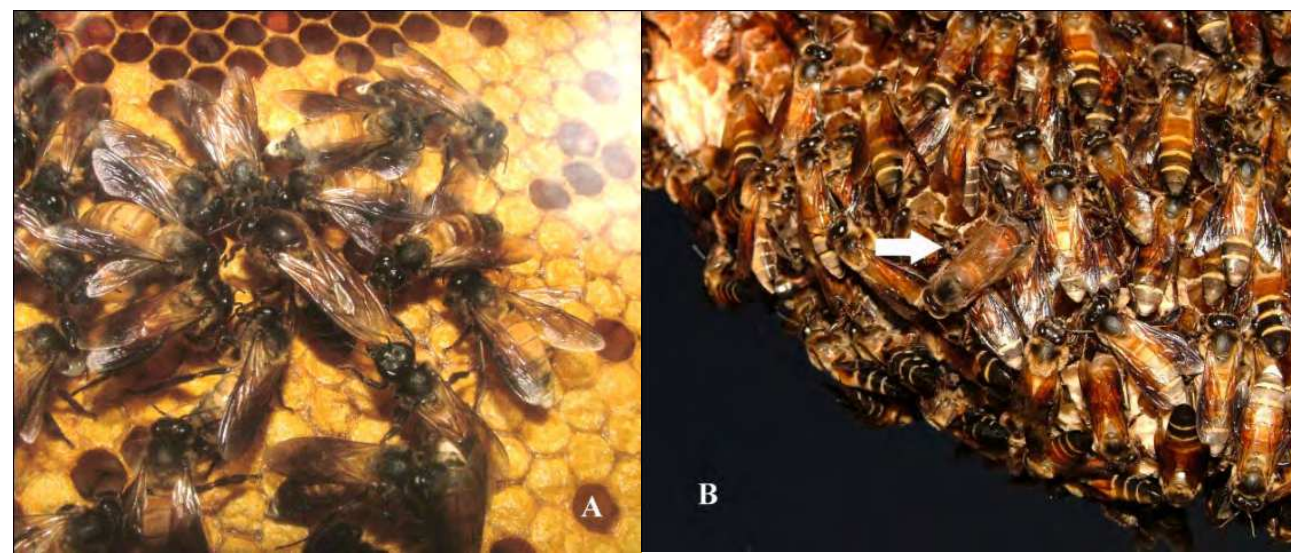

Fig. 1. The size dimorphism between castes of the giant honey bee, Apis dorsata F. is less pronounced than other Apis. (A) A queen is surrounded by her workers. Her thorax is slightly longer and broader than workers'. (B) Drones have larger eyes (white arrow) but are slightly shorter than workers. Photo by S. Wongvirat.

Within a hive, the queen is the only fertile female so she is the mother of all diploid (queen and worker) members (Crane, 1990), whilst she is typically (under normal circumstances) the mother of all unfertilized eggs (functional drones) as well. Interestingly, a virgin queen can mate with many drones, and so limits the chances of a matched mating (homozygous at the sex locus) and diploid male production (Gould \& Gould, 1988). Such high level of polyandry is especially the case for $A$. dorsata queens that have mating frequencies of up to 88.5 (Wattanachaiyingcharoen et al., 2003). Such polyandry, given sperm mixing, leads to asymmetrical levels of the genetic relatedness between workers within colonies and has a profound effect on the bee biology and on the evolution of sociality in bees (Oldroyd \& Wongsiri, 2006). A queen can release twenty or more pheromones from her mandibular gland (Crane, 1990). These queen pheromones are volatile compounds, which are important in ensuring colony cohesion within the nest and the dominance of the single queen that heads the colony. The queen's mandibular gland pheromenes induce retinue physiology and behavior in workers (Slessor et al., 1988). For instance, they inhibit the worker's ovary development leading to non reproductive females, and stimulate workers to release pheromones (e.g. Nasonov pheromone) attracting other workers. They can stimulate workers to forage and regulate worker coherence in a swarm or abscorn (Crane, 1990). 
Although workers are typically sterile, (in some circumstances some workers can lay unfertilized eggs which if left unattacked by other workers will develop as drones), they have many activities in a colony. For example, a very young adult worker cleans vacated brood cells. Then, at about five-days old, it can feed young larvae and a queen since its hypopharyngeal glands locating in its head are fully active to synthesize royal jelly. Later, these glands start to degenerate at 10-days-old (Crane, 1990). Next, the glands change to produce wax for comb building and to clean the colony. At about two weeks of age, the venom sac is full (Crane, 1990), and some worker bees become active as guards of the colony. As the workers develop from two to four weeks of age, their hypopharyngeal glands secrete increasing amounts of invertase and glucose oxidase, enzymes used in making honey from nectar (Gould \& Gould, 1988). At the final stage, the workers will go out of a hive to forage food.

Drones are normally fertile (haploid) males. In all Apis spp. except A. dorsata and A. laboriosa, drones are reared in drone cells on the periphery of the brood nest (Oldroyd \& Wongsiri, 2006). These cells are similar to the worker cells in shape and orientation, but the hexagous cells are about three times larger than those of workers (Gould \& Gould, 1988). Drones do nothing except leave the colony and mate with a virgin queen. Then, they die. The morphology of the honey bee penis (genitalia) is unique to the genus (Michener, 2007) so it is one of the most useful species identification characters (Radloff et al., 2011).

\section{Diversity and distribution of honey bees}

From Oldroyd \& Wongsiri (2006), three subgenera of honey bees are currently recognized (Table 1), and these differ in the location and structure of building their hive. The two dwarf honey bee species from the subgenera Micrapis, A. florea and A. andreniformis, build a single comb surrounding a twig, while the giant honey bees (subgenera Megapis), A. dorsata and A. laboriosa build a single massive comb under a branch or cliff overhanging or under the eves or roof of a building. Cavity-nesting honey bees (Apis), A. mellifera, A. cerana, A. koscheonikovi, A. nuluensis and A. nigrocincta, build multiple comb nest in cavities.

A recent molecular phylogeny (Lo et al., 2010) added two new taxa to the existing genus Apis, one each in the subgenera Megapis and Apis. Based on Bayesian and maximum parsimony phylogenetic trees, their analysis support recognition of $A$. indica (the plains honey bee of south India) as a separate group from the more broadly distributed $A$. cerana. In addition, it also supported classification of the giant Philippines honey bee, A. breviligula, as a separated species from the more broadly distributed lowland $A$. dorsata. Thus, three subgenera and 11 species of honey bee of genus Apis have been recognized. The distribution of these species is highly uneven (Fig. 2). Interestingly, nine of these 11 species of honey bee can be found in the South-east Asia region, and combined with molecular phylogentic estimates of diveregnce times within the genus, supports that Asia is the most likely birthplace of the Apis genus.

In Thailand, there are five Apis species which are A. andreniformis, A. florea, A. dorsata, A. cerana and A. mellifera (Rattanawannee et al., 2007). The first four species are native to Thailand but A. mellifera has been introduced by man (anthropogenic) into the country for the apicultural industry (Wongsiri et al., 1996). To recognize these four native species, Rattanawannee et al. (2010) revealed that geometric morphometric analysis of the single wing alone could be used to identify four Asian honeybee species in Thailand and that the sex of the individual does not impede identification. A description of each of the four native species in Thailand are provided below. 


\begin{tabular}{|c|c|c|c|c|c|}
\hline Main group & Subgenus & Species & Author & Common name & Thai name \\
\hline \multirow[t]{2}{*}{$\begin{array}{l}\text { Dwarf honey } \\
\text { bee }\end{array}$} & \multirow[t]{2}{*}{ Micrapis } & A. andreniformis & Smith (1858) & $\begin{array}{l}\text { Small dwarf honey bee } \\
\text { / Black dwarf honey } \\
\text { bee }\end{array}$ & $\begin{array}{l}\text { Pung mim } \\
\text { sidam/Pung } \\
\text { mim lek/ } \\
\text { Pung marn }\end{array}$ \\
\hline & & A. florea & Fabricius (1787) & $\begin{array}{l}\text { Dwarf honey bee / } \\
\text { Red dwarf honey bee }\end{array}$ & $\begin{array}{l}\text { Pung mim/ } \\
\text { Pung vee }\end{array}$ \\
\hline \multirow{3}{*}{$\begin{array}{l}\text { Giant honey } \\
\text { bee }\end{array}$} & \multirow{3}{*}{ Megapis } & A. laboriosa & Smith (1871) & $\begin{array}{l}\text { Giant mountain honey } \\
\text { bee }\end{array}$ & - \\
\hline & & A. dorsata & Fabricius (1793) & $\begin{array}{l}\text { Giant honey bee / } \\
\text { Common giant honey } \\
\text { bee }\end{array}$ & Pung luang \\
\hline & & A. breviligula & Maa (1953) & $\begin{array}{l}\text { giant Philippines } \\
\text { honey bee }\end{array}$ & - \\
\hline \multirow{6}{*}{$\begin{array}{l}\text { Cavity nesting } \\
\text { honey bee }\end{array}$} & \multirow{6}{*}{ Apis } & A. cerana & Fabricius (1793) & Eastern hive honey bee & Pung prong \\
\hline & & A. koschevnikovi & Enderlein (1906) & Red honey bee & - \\
\hline & & A. nigrocincta & Smith (1861) & Sulawesian honey bee & - \\
\hline & & A. nuluensis & $\begin{array}{l}\text { Tingek, Koeniger } \\
\text { and Koeniger (1996) }\end{array}$ & Mountain honey bee & - \\
\hline & & A. indica & Fabricius (1798) & Plains Honey Bee & - \\
\hline & & A. mellifera & Linnaeus (1758) & Western honey bee & Pung pun \\
\hline
\end{tabular}

Table 1. Three subgenera of the genus Apis Linnaeus.

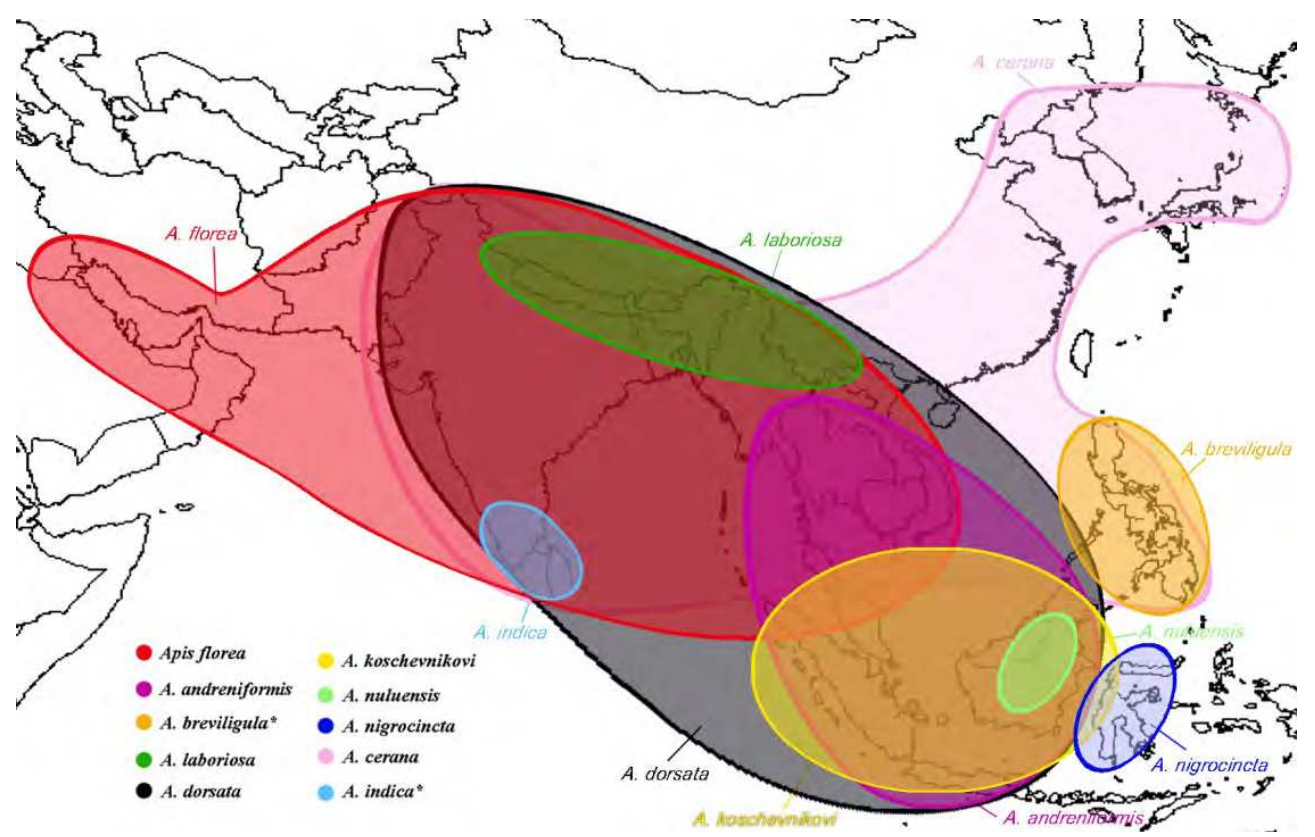

Fig. 2. Approximate distribution of 10 Asian honey bee species of genus Apis (amended in accordance with Ruttner, 1988; Oldroyd \& Wongsiri, 2006; Lo et al., 2010). 


\subsection{Dwarf honey bees, subgenus Micrapis}

The existence of two dwarf honey bee species (A. andreniformis and A. florea) as valid biological species is well revealed (Radloff et al., 2011), although they are mostly similar in worker and nest sizes. Both build an exposed single comb colony and may utilize similar resources in similar habitats (Wongsiri et al., 1996). Considering species-specific mophological characters, A. andreniformis workers have black hairs on their hind tibia and the dorsolateral surface of the hind basitarsus whilst $A$. florea workers have white hairs instead (Wu \& Kuang, 1987). In addition A. andreniformis workers also have black pigment all over which makes the bees look the darkest, while $A$. florea workers have less black pigment and so are mostly yellow bees (like red dwarf honey bees). The exception is the pigmentation of the scutellum, where in A. andreniformis it is yellowish, while that for $A$. florea tends to be black (Wongsiri et al., 1996). Furthermore, the abdominal segments of $A$. andreniformis queens and drones are all black, whilst in $A$. florea, queens present all orangeyellow abdominal segments while drones have grey abdominal segments with white hairs (Rinderer et al., 1995).

Although the endophalli of both species have a pair of bursal cornua, the morphology of the drone's endophallus is different in the two species. In A. florea the fimbriate has three protrusions with a strongly curved terminal whilst for $A$. andreniformis the fimbriate has six protrusions with thick and straight terminal. In addition, the thumb-like bifurcate basitasus of the hind leg of drones (Fig. 3) is comparatively longer in A. florea (Wu \& Kuang, 1987), being just under a half and $2 / 3$ that of the tibia length in A. andreniformis and A. florea, respectively (Wu \& Kuang, 1987).

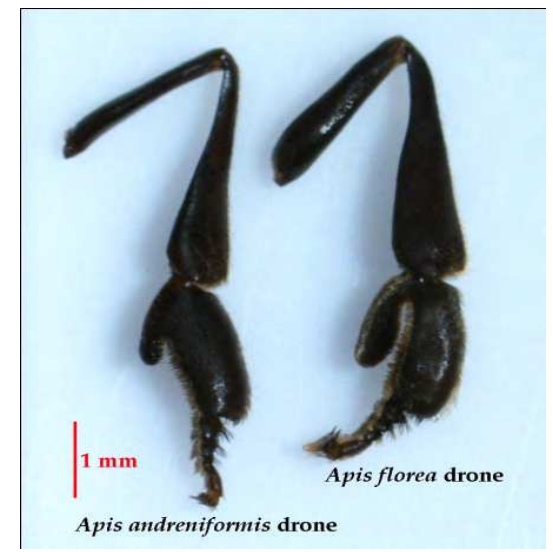

Fig. 3. Right hind leg of two dwarf honey bee drones showing the thumb-like bifurcate basitasus. Photo by A. Rattanawannee.

Although the nests of both species are very much alike (Figs. 4 and 5), some clear differences in the nest architecture are still observed. When viewed from the edge, cells in the honey storage area of $A$. florea nests are orientated inwards towards a supporting branch (Wongsiri et al., 1996). Considering a cross section of the crown of an A. florea nest, there are three levels of inter organization. The first level from the edge contains very long cells that extend to a supporting branch. The second level contains cells coming from the opposite side that have their base at the sides of cells coming from the other side. The third level contains cells 


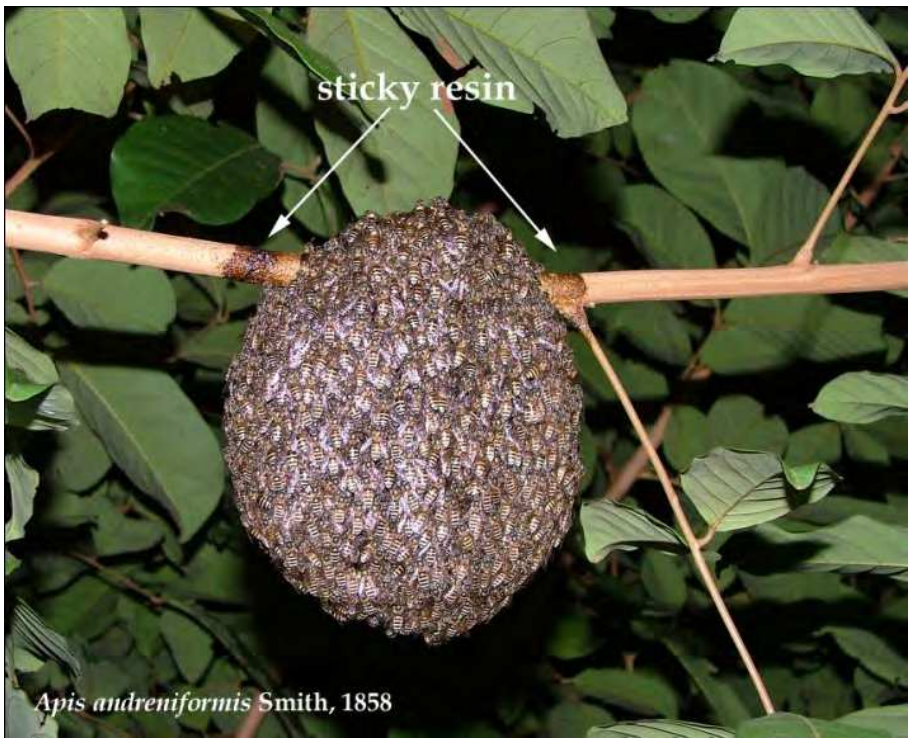

Fig. 4. A nest of Apis andreniformis in Thailand, showing the sticky resin around the supporting branches. Photo by S. Wongvirat.

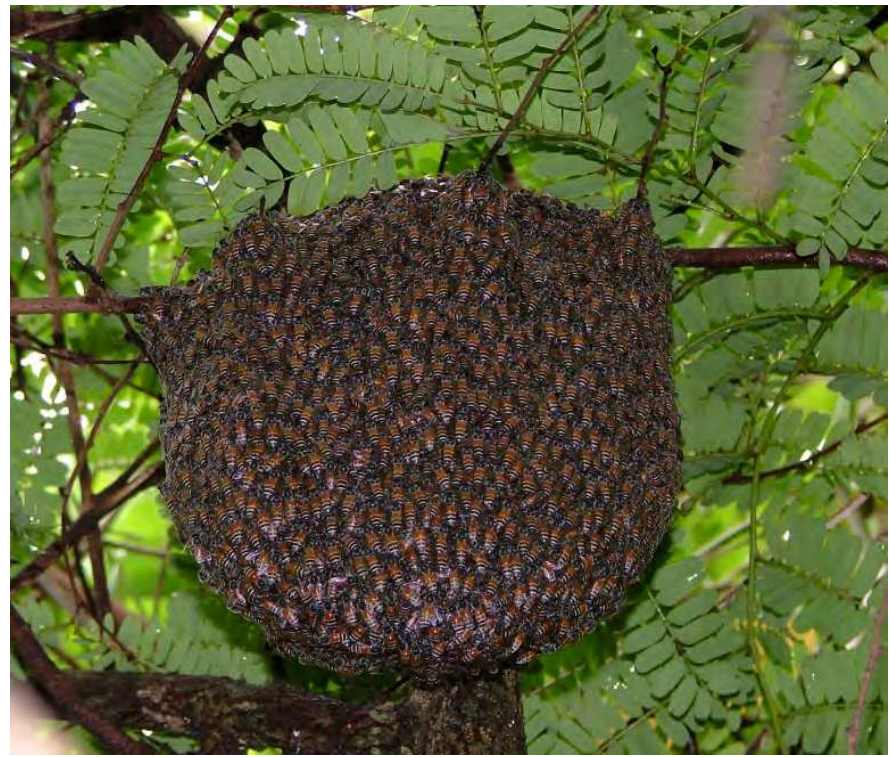

Fig. 5. An Apis florea nest in Thailand, showing that the comb is built around a small branch. Photo by $\mathrm{S}$. Wongvirat.

coming from the top of the honey storage area that have the same pattern as cells from the second level. However, some cells open to the top surface have their base well away from 
the supporting cell's base (Rinderer et al., 1996). As a consequence of the comb building process, the crown of $A$. florea nests do not contain a midrib (Oldroyd \& Wongsiri, 2006). These features contrast with the honey storage area in A. andreniformis's nests, where a characteristic crest appearance is evident when viewed from the outside. A cross section of the honey storage area of an A. andreniformis nest reveals a clear midrib structure where the bases of opposing cells come into contact as found in the brood area (Rinderer et al., 1996).

\subsubsection{Apis andreniformis Smith, 1858}

The black dwarf honey bee or small dwarf honey bee, A. andreniformis, is the smallest species in the genus Apis. It is widely distributed in the tropical and sub tropical regions of Asia, especially in the southern part of China, India, Burma, Laos, Vietnam, Malaysia, Indonesia and the Philippines (Fig. 2). It is always found at coastal flats and near foothill areas ( $1-100 \mathrm{~m}$ above sea level) to high mountain and forest areas at about $1600 \mathrm{~m}$ attitude (Wongsiri et al., 1996). The economic value of $A$. andreniformis has not been documented. However, the importance of the naturally occurring flora in the range of A. andreniformis probably depends on this bee species for pollination (Rinderer et al., 1995).

Since $A$. andreniformis is a rare and patchily distributed species, very little work has been reported. For example, intraspecific variation of $A$. andreniformis was reported by Rattanawannee et al. (2007). They sampled from 27 colonies (for morphometric analysis) and 32 colonies (for genetic analysis) of $A$. andreniformis throughout Thailand. In addition, three colonies for morphometric analysis and five colonies for DNA polymorphism were taken from Tenom in Sabah, Malaysia. For morphometry, 20 informative morphometric characters were used to assess the variation. Principle component analysis (PCA) yielded four factor scores. Within PCA plots, A. andreniformis from across Thailand and Tenom (Malaysia) formed a single group, a notion further supported by a hierarchical cluster analysis generated dendrogram. However, linear regression analysis showed clinal patterns of morphometric characters, where the body size of bees increased from the South to the North, associated with increasing altitude, but decreased from the West to the East, associated with decreasing altitude. For genetic variation, based on the sequence analysis of the mitochondrial cytochrome oxidase subunit $b(C y t-b)$ gene fragment, two groups of $A$. andreniformis populations from Thailand were found. However, these results are tentative, pending more extensive analyses of samples across the distribution areas of A. andreniformis.

\subsubsection{Apis florea Fabricius, 1787}

The red dwarf honeybee, A. florea, is extremly widespread in Asia, extending from Vietnam and southeastern China, across mainland Asia along and below the southern Himalayas, westwards to the Plateau of Iran and southern into Oman (Fig. 2) (Hepburn \& Hepburn, 2005). However, the main habitat of this bee species is Pakistan, India, Sri Lanka, Thailand, Indochina, Malaysia, part of Indonesia and Palawan at altitudes below $1000 \mathrm{~m}$ (Ruttner, 1988).

Multivariate morphometric analysis of $A$. florea using 20 morphometric characters to investigate the intraspecific morphometric variation of 18 samples of A. florea (360 bees) from Sri Lanka, Thailand, Pakistan, Iran and Oman revealed three morphocluster groups of A. florea (Ruttner, 1988); (i) Sri Lanka and south India, (ii) Thailand and Oman and (iii) Pakistan and Iran. In addition, the body size of A. florea was observed to increase across the study range from the South to the North. Subsequent analysis using 12 morphometric 
characters of $A$. florea from 26 localities in southern Iran revealed two morphoclusters of $A$. florea; a larger bee group at high latitudes $\left(29^{\circ}-34^{\circ}\right)$ and a smaller bee group at lower latitudes $\left(<29^{\circ}\right)$ (Tahmasebi et al., 2002). After combining their data with that of Ruttner (1988) and Mogga \& Ruttner (1988), they also identified three morphoclusters for all A. florea samples. However, information on the geographical contiguity of this honey bee species was still missing (Radloff et al., 2011).

To fill the geographical contiguity of $A$. florea, Hepburn et al. (2005) performed multivariate morphometric analysis of 184 colonies (2,923 individual workers) of $A$. florea collected from 103 localities across the full distributional area from Vietnam and southeastern China to Iran and Oman. They concluded that A. florea was a panmictic species comprised of three morphoclusters; northwestern, southeastern and an intermediate form. They suggested that the seasonality of reproductive swarming was temporary continuous allowing gene flow throughout this panmictic species.

In Thailand, Chaiyawong et al. (2004) performed multivariate morphometric analysis of 50 A. florea colonies (750 worker bees) from different locations throughout Thailand. From a PCA and cluster analysis of 22 morphometric characters, they revealed only a single group of A. florea in Thailand. Then, after reducing the number of characters, a degree of isolation from the mainland group was obtained for Samui Island and Pha-ngan Island, but the bees from these locations were correctly regarded simply as variants. This single morphocluster for Thailand of A. florea was in close agreement to the report of Nanork (2001), who found no variation among sympatric $A$. florea, in Thailand using PCR-RFLP analysis of the Cyt-bI$t R N A$ coding gene region of the mtDNA.

\subsection{Apis dorsata Fabricius, 1793}

The common giant honeybee, Apis dorsata, is one of three species of the subgenus Megapis. Neither Ruttner (1988) nor Engels (1999) separated A. dorsata from the closely related species, A. laboriosa. However, various evidences have demonstrated the difference between the two giant honey bee species. For example, Underwood (1990) reported the mating flight of Nepalese A. laboriosa drones was during 12:30 - 14:30 h whereas A. dorsata drone mating flight occured just after dusk, during 18:15 - 18:50 h (Koeniger et al., 1988), suggesting a prezygotic reproductive barrier. Also, the vocal communication dance performed by $A$. dorsata workers is different from that of the silent A. laboriosa workers (Oldroyd \& Wongsiri, 2006; Kirchner et al., 1996). Furthermore, Arias \& Sheppard (2005) revealed that the ND2 and EF-1a gene nucleotide DNA sequence divergence between A. dorsata and A. laboriosa is $10.6-11.5 \%$, which strongly supports seperate species status. Indeed, Raffiudian \& Crozier (2007) showed that $100 \%$ of Bayesian consensus trees support the grouping of $A$. dorsata distinct from A. laboriosa, and supporting recognition of $A$. laboriosa as a valid species.

Other than A. dorsata and A. laboriosa, another species of giant honey bees has been reported by Lo et al. (2010). Based on Bayesian and maximum parsimony phylogenetic trees, their analysis supports recognition of the giant Philippines honey bee, A. breviligula Maa, 1953, as a separate species from the more broadly distributed lowland A. dorsata. A. breviligula is found northwest of the Merrill line in Luzon in the Philippines (Oldroyd \& Wongsiri, 2006). This giant honey bee is strikingly distinguished from $A$. dorsata owing to black rather than yellow coloration of the abdomen and that it never forms colony aggregations as A. laboriosa and $A$. dorsata do (Lo et al., 2010). Therefore, three species of giant honey bee in the subgenus Megapis of the genus Apis have now been recognized. 
The distribution of $A$. dorsata is over a vast geographic area in the South and Southeast Asia (Fig. 2). To the West, A. dorsata occurs not farther than the Indus river, and to the East, $A$. dorsata are throughout the Philippines and even cross the Wallace line. The giant honey bee is reported to present at altitudes up to 1000 - $1700 \mathrm{~m}$, or even up to $2000 \mathrm{~m}$ during migration (Ruttner, 1988).

In Thailand, $A$. dorsata is the only species of the subgenus Megapis that can be found. Among honey bee spp., individual workers of $A$. dorsata are relatively large, being about $17 \mathrm{~mm}$ long. Thus, the giant honey bees are distinguished from the other four honey bee species in Thailand by their much larger body size and that their wings that are fuscous, and quite hairy (Oldroyd \& Wongsiri, 2006). The fore and hind wings of $A$. dorsata workers are 12.96 and $8.91 \mathrm{~mm}$ long, respectively (Tan, 2007). The body color of A. dorsata workers is yellow, with tergites 2 and 3 being reddish-brown (Crane, 1990). Unlike the comb of the dwarf honey bees (A. florea and A. andreniformis), in which the crown of the comb always encircles the support, the massive single comb colony of $A$. dorsata is always attached under the surface of a stout tree branch or an overhang of a rock face, and nowadays also sometimes to the eves of buildings or other urban structures (Fig. 6) (Paar et al., 2004).

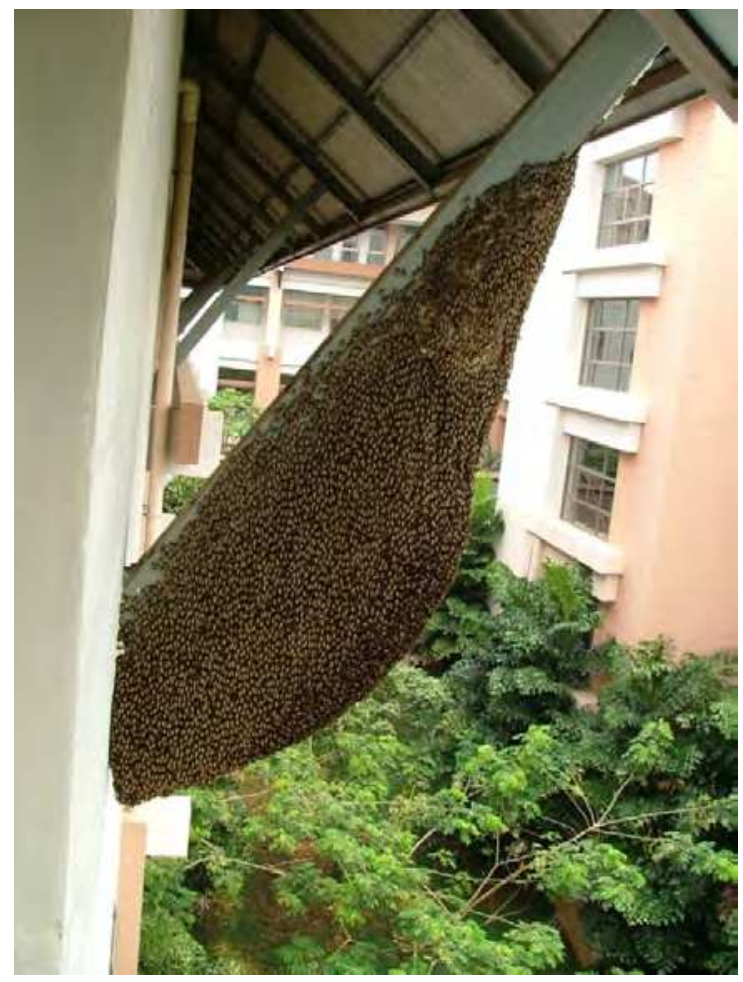

Fig. 6. A masive single comb nest of Apis dorsata attached under the eves of buildings at Mae Fah Luang University, Chiang Rai, Thailand. Photo by A. Rattanawannee.

Where A. dorsata nests are found in trees, the diameter of the supporting branches varies from $12-30 \mathrm{~cm}$ (Morse \& Laigo, 1969) or much larger (Oldroyd \& Wongsiri, 2006). A 
slightly sloping branch is preferred (Tan et al., 1997). The width of A. dorsata combs varies from $43-162 \mathrm{~cm}$, and the height from $23-90 \mathrm{~cm}$ (Tan, 2007). Honey is stored in one corner of the comb nearest the uppermost section of the comb in an area about $10-20 \mathrm{~cm}$ in a large nest (Oldroyd \& Wongsiri, 2006). In the large colonies, the number of individual workers can be over 50,000 (Morse \& Laigo, 1969). About 3 - 4 weeks after nesting, a colony of $A$. dorsata typically has about $4 \mathrm{~kg}$ of stored honey in the comb, but the highest recorded amount is $15.7 \mathrm{~kg}$ (Tan, 2007).

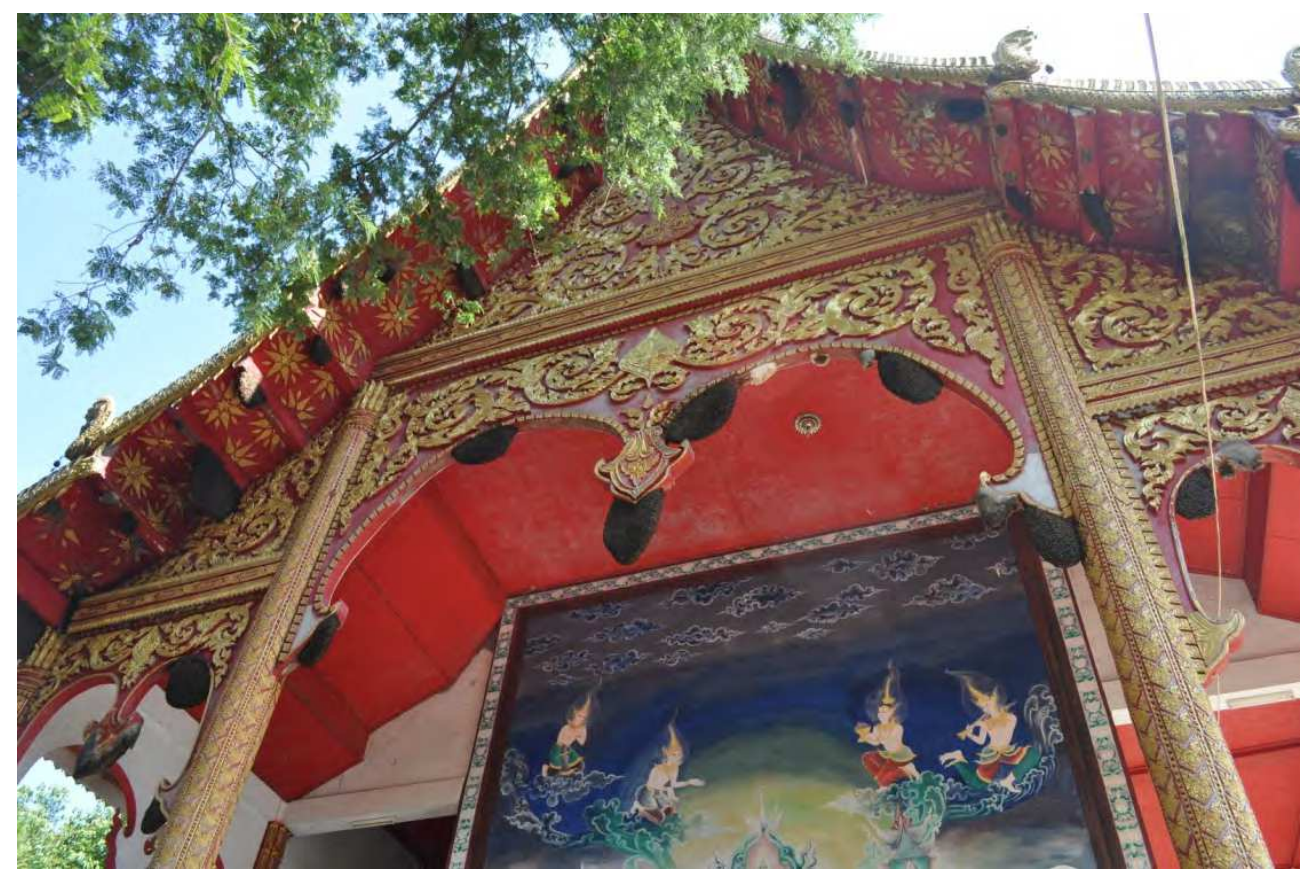

Fig. 7. An aggregation of Apis dorsata colonies under the roof of a temple in Chaing Rai, Thailand. Photo by A. Rattanawanee.

Three further typical characters of $A$. dorsata are as follows. First, colonies are unusual in terms of that nests often occur in dense aggregations of up to 100 or even 200 colonies on a single tree or building (Koeniger \& Koeniger, 1980), and these colonies are often separated by only a few centimeters (Figs. 7 and 8). Secondly, the nest sites are occupied seasonally year after year. Interestingly, queens often return to the same nest site even after an absence of up to 18 months (Paar et al., 2000). In Thailand, aggregations of nests are formed by swarms that arrive at the onset of the dry season. Finally, colonies usually display seasonal migration between alternate nesting sites. Nest sites of these bee populations tend to be occupied for 3 - 4 months (Paar et al., 2004). Towards the end of this period, colonies abscond, leaving an empty comb (Fig. 8). The swarms leave the nest site to a new site up to $200 \mathrm{~km}$ away (Koeniger \& Koeniger, 1980), and most like spending the wet season as combless swarms in mountainous regions (Ruttner, 1988). The proximate cause of migration may be related to available flowers. Abscornding A. dorsata have been observed to travel among habitats with different blooming seasons (Crane et al., 1993). The migration of 
colonies may also contribute to control infections with the parasitic mite Tropilaelaps clareae, since it needs bee brood in order to reproduce (Paar et al., 2004). Therefore, colonies may reduce infestation levels by this parasitic mite with a period of broodless migration (Rinderer et al., 1994).

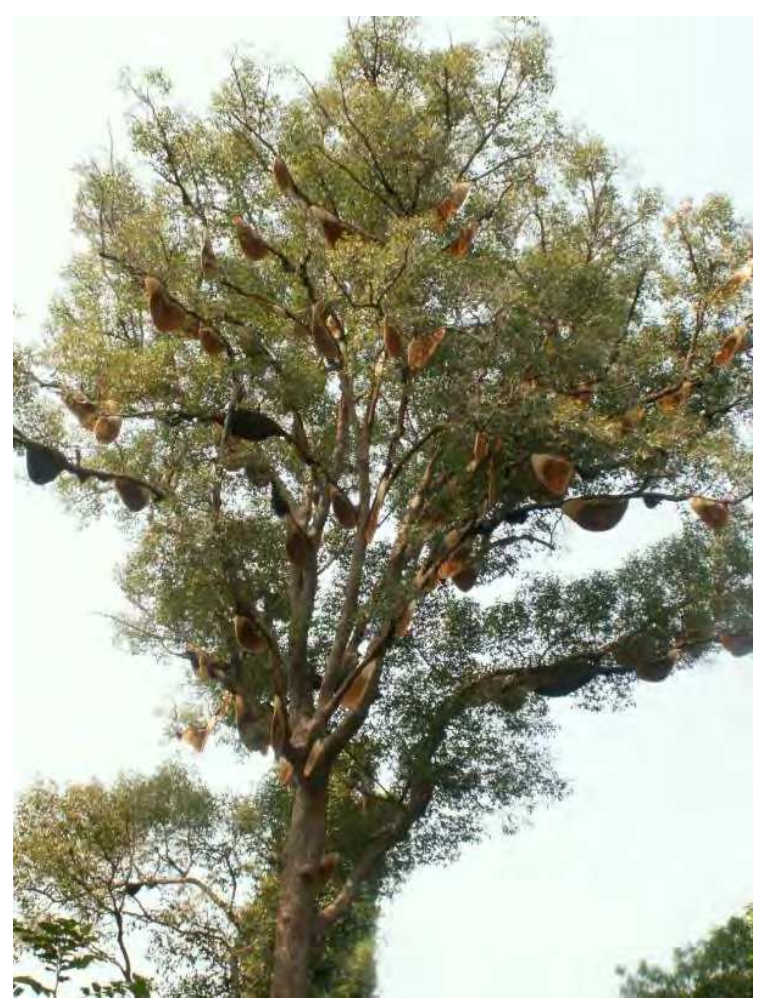

Fig. 8. Absconding nests within a colony aggregation of $A$. dorsata on a single tree in Sakonnakorn, Thailand. Photo by A. Rattanawannee.

\subsection{Apis cerana Fabricius, 1793}

A. cerana can be found throughout Asia, including in the great mountain ranges and deserts (Ruttner, 1988), except that there is no evidence of $A$. cerana occurrence in the northern Japanese island of Hokkaido. In contrast, it is widely distributed over the other islands in Japan. In Southeast Asia, A. cerana is restricted to the Malayan region, the West of the Wallace line (Ruttner, 1988, as shown in Fig. 2).

A. cerana is a medium sized bee (in body length) with a fore wing length of $7-10 \mathrm{~mm}$ (Oldroyd \& Wongsiri, 2006). Feral colonies of A. cerana are found in a similar location as $A$. mellifera colonies, such as tree hollows, clefts in rocks and walls (Fig. 9) (Ruttner, 1988). They usually build three or more parallel combs attached to the roof of tree hollows (Fig. 10). Among the native Thai honey bee species, only A. cerana can be maintained in hives like $A$. mellifera (Wongsiri et al., 1986). However, traditional hives for A. cerana are substantially smaller than those constructed for A. mellifera (Ruttner, 1988). 


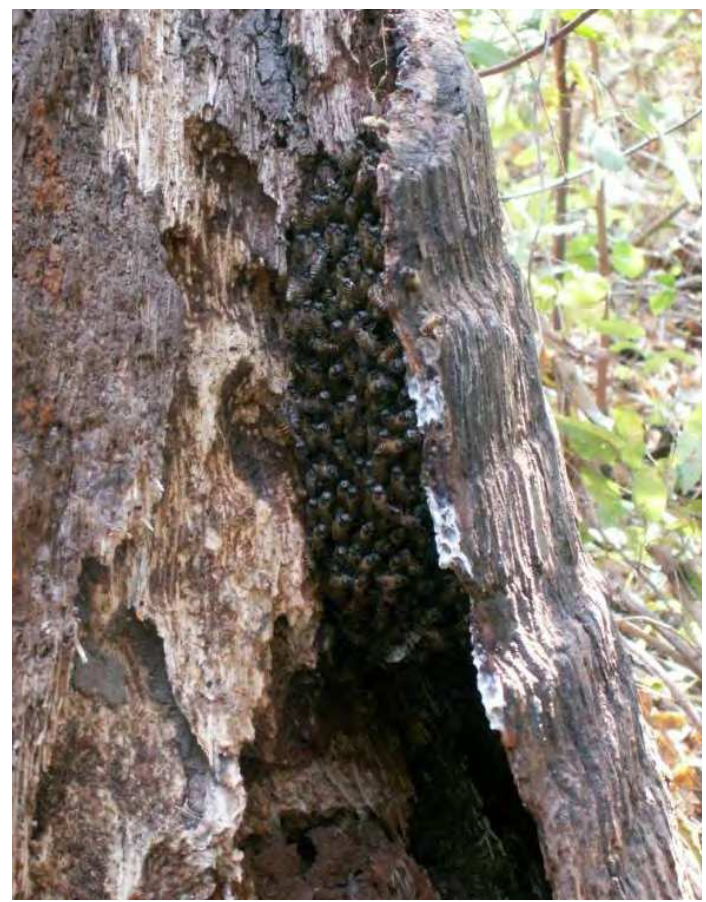

Fig. 9. A feral colony of Apis cerana in a coconut tree hollow in Samut Songkham, Thailand. Photo by J. Kaewmuangmoon.

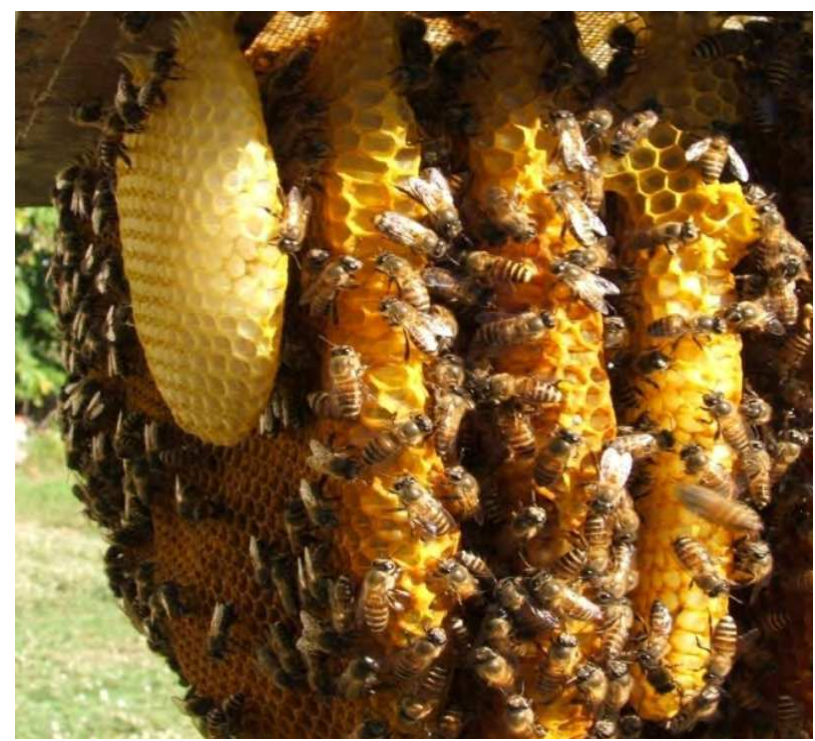

Fig. 10. Multiple combs withinan A. cerana nest. Photo by P. Nanork. 
The first morphometric analysis of A. cerana was reported in Ruttner (1988), where the results of a PCA using 40 morphometric characters on 93 samples (18 Asian countries) revealed four main groups. Group I consisted of A. cerana collected from South India, Sri Lanka, Bangladesh, Burma, Malaysia, Thailand, Indonesia and the Philippines, whereas A. cerana from Afghanistan, Pakistan, North India, China and Vietnam were classified in Group II. A. cerana samples from central and east Himalaya belonged to Group III whilst Group IV contained A. cerana from Japan.

In Thailand, Limbipichai (1990) successfully used standard morphometrics to verify a geographic subpopulation of $A$. cerana split by the Isthmus of Kra, a biogeographic transition area $\left(12^{\circ} \mathrm{N}\right.$ latitude). This morphometric result was supported by Deowanish et al. (1996) who used PCR-RFLP analysis of the tRNA leu - COII region mitochondrial DNA sequence based analysis and found variation in the PCR-RFLP banding patterns among Thai samples when using BglII, EcoRV, HaeIII, HinfI and NdeI. In addition, A. cerana from the South of Thailand (Hatyai and Samui) could be clearly separated from the mainland population when the tRNAleu - COII region containing amplicon was digested by EcoRV and HindIII. In some support of this, Sihanuntavong et al. (1999) also reported that the A. cerana population from the Samui islands (South of Thailand) was distinct from the mainland populations, as determined using PCR-RFLP anlaysis using DraI restriction of the PCR amplicons of the srRNA and IrRNA gene and COI-COII coding regions. Likewise, Songram et al. (2006) revealed eight distinct RFLP patterns of the ATPase6-ATPase8 gene region when the DNA was digested by $V s p I$. Overall, a strong biogeographic pattern between the northern and southern latitude bee populations in Thailand was revealed.

\section{Stingless bees}

Meliponini is one of the 19 tribes in the subfamily Apinae, including Apini, Euglossini and Bombini (Michener 1974, 2000). Apini and Meliponini are the two tribes that contain members that display a high level of social behavior (Arias et al., 2006). Meliponines are groups of stingless bees whose size, body color and appearance vary greatly. For example, stingless bees in some species have a slender body while those in other species have a wide body. Some appear shiny and others as hairy somewhat like small bumble bees. Also, stingless bees in some species look metallic (Crane, 1990). The number of stingless bee species of Meliponini is still controversial, but it is estimated to be about 50 times more species than Apis spp. (Roubik, 2006). Currently, over 600 species in 56 named genera have been recorded in the tropical and subtropical regions of the world. Of these, 400 known species exist in the Neotropical regions and at least 45 species were described in Southeast Asia (Cortopassi-Laurino et al., 2006).

Stingless bees and honey bees are both classified as highly eusocial insects (Michener, 2000), with large perennial colonies, morphologically distinct worker and queen castes and an intricate division of labour and recruitment to food sources (Peter et al., 1999). They normally have a single egg-laying queen and reproduce by division of a colony between the mother queen and a daughter, which is called reproductive swarming (Roubik, 1989).

Meliponines differ from honey bees of the genus Apis in many biologically significant ways. For example, they generally have no sting, do not use water to cool their nest and pure wax to build it, and the males feed at flowers while the gravid queens cannot fly (Roubik, 2006). Moreover, Peter et al. (1999) showed that single mating is the rule in stingless bees; in contrast to the well-known multiple mating of honeybee queens (Oldroyd et al., 1997), since 
diploid males (from sex allele matched matings) are not tolerated and lead to the queen bee being usurped.

Stingless bees nest in cavities, which differ in locality between species and may be underground, in tree or other enclosed spaces, such as buildings and termite nests (Crane, 1990). Stingless bee species are recognizable from the characteristic nest entrances and often their particular site (Roubik, 2006). Nests are made of wax secreted from the metasomal terga mixed with resins and gums collected by stingless bee workers. Some species add mud, feces or other materials to certain parts of the construct. In all Meliponine species, the composition and texture differ in different parts of the nest (Michener, 2000). Unlike honey bees, they produce brood in the manner of a solitary bee with an egg placed on top of a food mass in a sealed cell (Michener, 2000). Inside the nest of stingless bees, there are different shapes and arrangements of brood cells and food storages (Fig. 11). Brood cells in many stingless bee species are spherical to ovoid, while food storage containers are small to large spheres, or are egg-shaped, or even conical or cylindrical (Roubik, 2006). Honey and pollen are usually stored in separated containers called "storage pots". Usually, pots are constructed together in conglomerates, as are the brood cells. Interestingly, the horizontal brood cells of stingless bees open upwards and are closed after an egg is laid. The egg is positioned on the semi-liquid mix of honey, hypopharyngeal-gland secretion and pollen. All brood cells are destroyed by workers after use and cannot be reused as they are in honey bees (Michener, 2007).

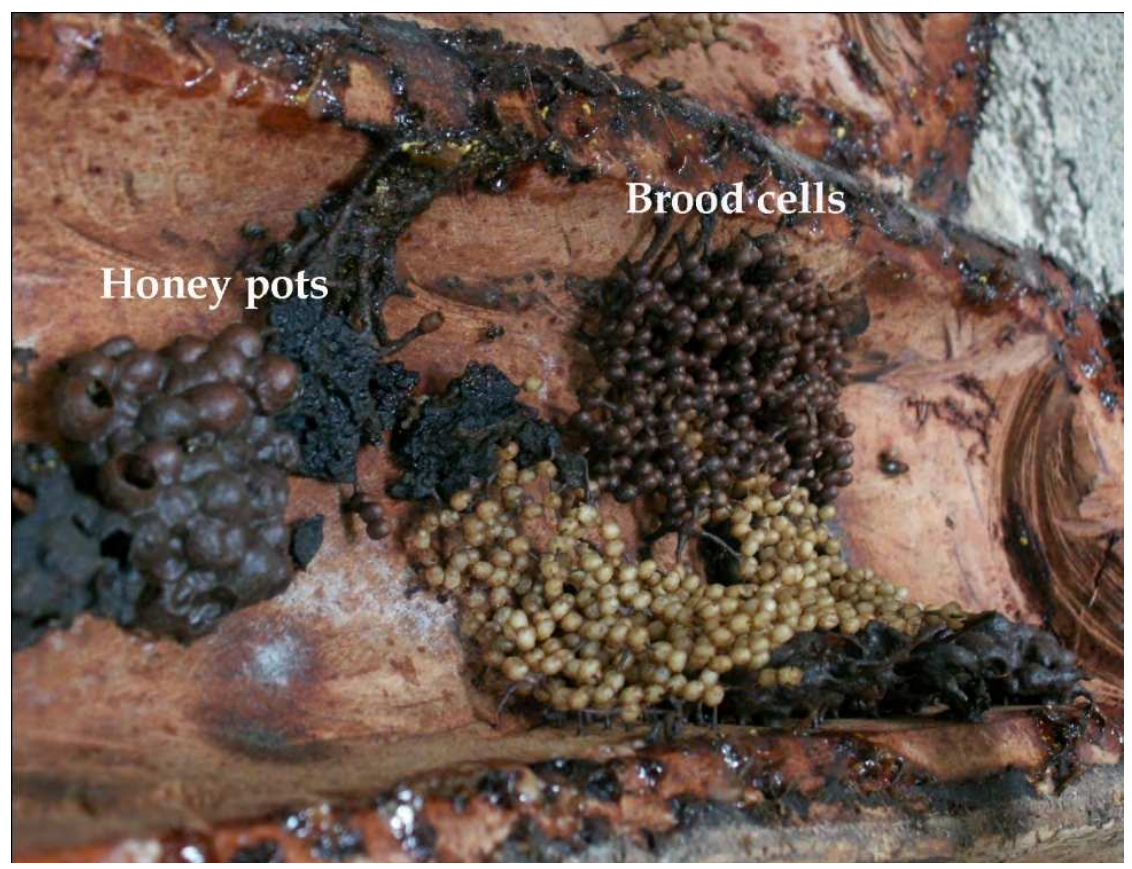

Fig. 11. Ovoid brood cells and honey pots within a Trigona laeviceps nest are separated.

More than 50 genera of Meliponines have been reported (Arias et al., 2006). In Thailand, only one genus, Trigona, is recognized as endemic with 32 species currently reported 
(Klakasikorn et al., 2005). However, this genus is found extensively in tropical regions. In the Neotropics it ranges from Mexico to Argentina, in the Indo-Australian region it extends from India and Sri Lanka to Taiwan, the Solomon islands, South Indonesia, New Guinea and Australia (Michener, 2000). The Thai name for stingless bees varies across the regions, and are Channa Rong (Central), Kheetung Nee (North), Khee Suit (Northeast), and Oong (South).

\section{Value of bees}

\subsection{Pollination value}

Up to a third of the food we eat is derived from plants that are either dependent on or benefit from insect pollination (Oldroyd \& Nanork, 2009), especially by honey bees (Richards, 2001). The European honey bee, Apis mellifera, is the most economically valuable pollinator of agricultural crops worldwide (Conte \& Navajas, 2008). However, in most areas of Southeast Asia, there is no significant pollination industry. Insect pollinated crops are, therefore, completely reliant on wild bees, particularly honey bees and stingless bees, for their pollination (Rahman \& Rahman, 2000).

Because of their dance language and broad foraging length, honey bees can rapidly identify and exploit the available flowers for nectar and or pollen or plant sap for propolis over a wide range (Dornhaus et al., 2006). Therefore, honey bees are better at long-distance dispersal of pollen than solitary arthropods (Oldroyd \& Wongsiri, 2006). Circumstantially, honey bees may partially compensate for fragmentation by bridging the gaps between isolated plant communities (Johnson \& Steiner, 2000). Corlett (2001) reported that 86\% of plant species in an extremely disturbed area in Hong Kong were visited by A. cerana. Thus, although A. cerena is probably not a pollinator of all these plants, it does appears to maintain Hong Kong's diverse flora.

Lychees, Litchi chinensis Sonn., is one of the important commercially grown economic fruit plants in Thailand. Field trials suggested that the reduction of fruit yield by as much as $11.2 \%$ occurs in the absence of pollinators (Oldroyd \& Wongsiri, 2006, as cited in Sihag, 1995), and that the majority of pollinators are honey bees and stingless bees. Wongsiri et al. (1996) reported that $A$. florea and A. andreniformis are excellent orchard and field crop pollinators, including for longan (Dimocarpus longan Lour.) and mango (Mangifera indica L.). Since A. florea is easy to maintain in orchards and is abundant throughout Thailand, this dwarf honey bee is an excellent pollinator for economic crops and wild plants (Ruttner, 1988).

The lowland forests of Asia are dominated by trees in the family Dipterocarpaceae. Since an individual tree of each species tends to be over the long distances required for efficient effective fertilization and gene flow (Itioka et al., 2001). This requires an animal vector that has species fidelity while foraging, a large foraging range, and the tendency to visit multiple trees, either as individual foragers, or via transfer of pollen among foragers in the nest. The giant honeybee has all these characteristics (Oldroyd \& Nanork, 2009). In addition, Momose et al. (1998) reported that $A$. dorsata is one of the major pollinators of several dominant components of the forest canopy in Southeast Asian lowland Dipterocarp forests, one of the richest terrestrial ecosystems in the world. It was reported that $A$. dorsata pollinated at least 15 species of emergent and canopy trees at Lambir (Momose et al., 1998) and was the dominant pollinator of the upper strata in rainforests in peninsular Malaysia (Appanah, 1993), and for canopy dipterocarps in Sri Lanka (Dayanandan et al., 1990). 


\subsection{Products value}

Bee products (honey, royal jelly, propolis, bee pollen, wax and bee venom) are of increasing economic importance. Honey is always consumed as food while royal jelly, propolis and bee pollen are useful in nutrient supplements and applied in cosmetics and traditional medicine. Furthermore, bee venom has long been used in Apitherapy. Among the different bee products in Thailand during 2008 - 2010, honey seems to be the only world trade product according to the statistical record of Thai Custom Department, Ministry of Finance of Thailand (Tables 2 and 3).

It is obvious that China's market is the biggest, both in terms of importation and exportation. Interestingly, the US exports the highest quantity of honey while relatively only a small quantity is consumed in the country. Although China exports a high quantity of honey, a much higher quantity of imported honey is observed. In contrast, Germany is the leading exporter of honey overseas. In addition, although there are many bee farms in countries such as Thailand, Myanmar and Australia, large quantities of honey still have to be imported. This suggests that a promotion program in bee apiary should be arranged and supported.

\begin{tabular}{lllllll}
\hline Country & \multicolumn{2}{c}{ 2008 A.D. } & \multicolumn{2}{c}{ 2009 A.D. } & \multicolumn{2}{c}{2010 A.D. } \\
\cline { 2 - 7 } & $\begin{array}{l}\text { Quantity } \\
\text { (ton) }\end{array}$ & $\begin{array}{l}\text { CIF value } \\
\text { (million } \\
\text { baht) }\end{array}$ & $\begin{array}{l}\text { Quantity } \\
\text { (ton) }\end{array}$ & $\begin{array}{l}\text { CIF value } \\
\text { (million } \\
\text { baht) }\end{array}$ & $\begin{array}{l}\text { Quantity } \\
\text { (ton) }\end{array}$ & $\begin{array}{l}\text { CIF value } \\
\text { (million } \\
\text { baht) }\end{array}$ \\
\hline Australia & 150.26 & 17.39 & 112.44 & 14.48 & 119.64 & 18.75 \\
China & 35.96 & 0.61 & 431.38 & 14.00 & $1,222.11$ & 57.11 \\
France & 14.58 & 3.83 & 11.24 & 3.17 & 14.99 & 3.54 \\
Germany & 23.68 & 6.16 & 23.96 & 6.89 & 24.04 & 6.12 \\
Japan & 14.03 & 2.12 & 14.12 & 2.67 & 9.7 & 1.92 \\
Laos & 0.03 & 0.00 & $\mathrm{ND}$ & $\mathrm{ND}$ & 18.60 & 1.36 \\
Malaysia & $\mathrm{ND}$ & $\mathrm{ND}$ & 0.28 & 0.01 & 0.86 & 0.18 \\
Myanmar & 0.2 & 0.00 & 0.08 & 0.00 & $1,094.68$ & 31.13 \\
Switzerland & 3.29 & 1.08 & 1.00 & 0.36 & 3.00 & 1.04 \\
Thailand & 1.79 & 0.41 & 1.79 & 0.31 & 251.40 & 8.57 \\
UK & 3.15 & 0.94 & 2.53 & 0.72 & 8.16 & 2.10 \\
USA & 0.00 & 0.00 & 0.00 & 0.00 & 0.14 & 0.02 \\
\hline
\end{tabular}

Table 2. Honey imports (2008 - 2010). The data was obtained from Thai Custom Department, Finance Ministry, Thailand. ND represents no data. 


\begin{tabular}{lllllll}
\hline Country & \multicolumn{2}{c}{2008 A.D. } & \multicolumn{2}{c}{ 2009 A.D. } & \multicolumn{2}{c}{2010 A.D. } \\
\cline { 2 - 7 } & $\begin{array}{l}\text { Quantity } \\
\text { (ton) }\end{array}$ & $\begin{array}{l}\text { FOB value } \\
\text { (million } \\
\text { baht) }\end{array}$ & $\begin{array}{l}\text { Quantity } \\
\text { (ton) }\end{array}$ & $\begin{array}{l}\text { FOB value } \\
\text { (million } \\
\text { baht) }\end{array}$ & $\begin{array}{l}\text { Quantity } \\
\text { (ton) }\end{array}$ & $\begin{array}{l}\text { FOB value } \\
\text { (million } \\
\text { baht) }\end{array}$ \\
\hline Australia & ND & ND & ND & ND & 0.00 & 0.00 \\
China & 400.53 & 38.58 & 174.16 & 12.33 & 447.32 & 32.02 \\
France & 4.00 & 0.83 & 8.54 & 0.96 & 637.93 & 49.82 \\
Germany & 140.10 & 10.29 & 169.22 & 11.96 & 658.20 & 44.48 \\
Japan & 2.68 & 0.29 & 5.76 & 0.60 & 2.56 & 0.33 \\
Laos & $\mathrm{ND}$ & $\mathrm{ND}$ & 0.11 & 0.02 & 0.04 & 0.00 \\
Malaysia & 272.34 & 14.69 & 252.90 & 16.20 & 269.11 & 32.22 \\
Myanmar & $\mathrm{ND}$ & $\mathrm{ND}$ & $\mathrm{ND}$ & $\mathrm{ND}$ & $\mathrm{ND}$ & $\mathrm{ND}$ \\
Switzerland & $\mathrm{ND}$ & $\mathrm{ND}$ & $\mathrm{ND}$ & $\mathrm{ND}$ & 0.00 & 0.00 \\
Thailand & $\mathrm{ND}$ & $\mathrm{ND}$ & $\mathrm{ND}$ & $\mathrm{ND}$ & $\mathrm{ND}$ & $\mathrm{ND}$ \\
UK & 1.79 & 0.35 & 1.79 & 0.26 & 79.03 & 4.67 \\
USA & 186.09 & 10.18 & $1,954.86$ & 95.51 & $1,815.79$ & 92.75 \\
\hline
\end{tabular}

Table 3. Honey exports (2008 - 2010). The data was obtained from Thai Custom Department, Finance Ministry, Thailand. ND represents no data.

\section{Application of bee products}

Not only are bee products consumed as food, as mentioned earlier, but they also have long been used in medical aspects, especially in traditional medicine. Bee products are derived from plants. For example, honey is the modified form of plant nectar by alpha-glucosidase (Kubo et al., 1996). Propolis is collected from plant buds and barks (Castaldo \& Capasso, 2002). Since it is hard to control the consistency of bioactivities from natural products, both in their original form and crude extract, it is important to obtain a chemical structure of the active compounds for subsequent chemical synthesis or (bio) assay of the active contents. Many purification steps were used in order to obtain a pure compound. To this end, spectroscopic techniques, such as Infrared spectroscopy (IR) and Nuclear Magnetic Resonance (NMR), have been broadly applied. Once the structures of the bioactive compounds are known, it can lead into their chemical synthesis and or serve as templates for modifications for subsequent drug development. Currently, the bioactive chemical compounds found in propolis and honey, which mainly belong to the groups of flavonoids and phenolic compounds, seem to be similar to those found in the pollen or sap of the foraged plants (Katircioglu \& Mercan, 2006), as expected. Some of the bioactivities from bee products are briefly outlined below.

\subsection{Antimicrobial activity}

Anti-bacterial activity has been reported against pathogenic bacteria for bee products, and especially propolis and honey (Boorn et al., 2010). Overall, Gram positive bacteria are more 
sensitive to the bee products than Gram negative bacteria (Marcucci et al., 2001). Active compounds may act on the inhibition of bacterial RNA polymerase (Takaisi \& Schilcher, 1994), degrade the cytoplasmic membrane of bacteria (Cushnie \& Lamb, 2005) or cause bacteria to lose their capacity to synthesize ATP, membrane transport and mobility (Mirzoeva et al., 1997). For example, the proliferation of Staphylococcus aureus (Gram ${ }^{+v e}$ bacteria) and Escherichia coli (Gram-ve bacteria) is inhibited by the propolis of Melipona compressipes (Kujumgiev et al., 1999). Furthermore, propolis collected from the same bee species but in different regions, or different bee species in the same region show marked differences in bioactivity levels as well as susceptible microbes, as expected given the different flora available or utilized by the different bee species in different regions. For example, propolis collected from Spain yielded a higher antimicrobial activity than that collected from Mongolia (Kujumgiev et al., 1999).

However, such geographical and likely seasonal variations in the bioactivity of bee products necessitates some form of standardization of their bioactivity. There has been some progress in the improvement of the standard and acceptance in using bee products in medicine, especially medical-grade honey (Kwakman et al., 2011). Manuka honey, is one such medical-grade honey with antibacterial bioactivity (Lin et al., 2011). Given the severe problem of bacterial resistance to antibiotics, such as methicillin-resistant $S$. aureus, there is a growing need to find new antimicrobial agents. Interestingly, honey from A. mellifera in Ireland (Maeda et al., 2008) and from T. laeviceps in Thailand (Jirakanwisal, 2010) can inhibit the growth of methicillin-resistant $S$. aureus in vitro better than the currently used antibiotics. In addition, other antibiotic-resistant bacteria, such as gentamicin-resistant E. coli, methicillin-resistant S. epidermidis, vancomycin-resistant Enterococcus faecium, could be killed by medical-grade honey (Kwakman et al., 2008).

Other than pathogenic bacteria, antifungal activity has been reported for bee products, such as the in vitro inhibition of Candida albicans growth by propolis from Brazil (Kujumgiev et al., 1999). Interestingly the antifungal activity of the propolis extract from A. mellifera against Phomopsis spp., Fusarium spp. Trichoderma spp. and Penicillium notatum was greater than that seen with ketoconazole, an antifungal drug (Quiroga et al, 2006).

In addition to bacterial and fungal pathogens are severe human diseases caused by viruses. Due to their high rate of mutation, the development of new antiviral agents is always required. With respect to bee products, in 1999, Kujumgiev et al. presented that the aromatic acids and flavonoid aglycone compounds in the propolis from $M$. compressipes in Brazil could inhibit the growth of avian influenza virus in vitro. Furthermore, the in vitro replication of herpes simplex virus was also inhibited by propolis (Erukhimovitch et al., 2006) and honey (Banerjee, 2006).

\subsection{Anti-inflammatory activity}

Inflammation is part of the immune and general tissue damage defense response of the vascular tissues, such as for aiding removal of invading pathogens, intruders, which can be microbes, wounds, allergenic proteins, auto-immune, some chemicals, and removing damaged or necrosing tissues Although required for the healing process and part of the immune response, as outlined above, inappropriate or chronic inflammation is deleterious and can lead to, for example, asthma, atherosclerosis and rheumatoid arthritis as well as pain and poor healing. Each individual is differently susceptible to the anti-inflammatory agents or drug. It is still necessary to find out a new anti-inflammatory agent. However, this response can be inappropriate or too extreme and detrimental, driving the requirement for 
topical, specific and systemic agents to control the anti-inflammatory responses. With respect to bee products, Paulino et al. (2003) reported an anti-inflammatory activity in the ethanolic extract of propolis from A. mellifera in Bulgaria, which had a similar antiinflammatory activity level to that provided by indomethacin, a recent anti-inflammatory drug. Subsequentially, $\mathrm{Hu}$ et al. (2005) reported that the water and ethanolic extracts of propolis from $A$. mellifera in China could significantly decrease the swollen symptoms within two hours of treatment.

Other than propolis, an anti-inflammatory activity can be provided by bee pollen, such as that reported in the ethanol extract of pollen from A. mellifera in Brazil (Medeiros et al., 2008). The main active compounds were found to be phenolic compounds and furthermore these were similar to those found in various plants, such as berry, vegetables, fruits and tea leaves. Moreover, it was reported that the flavanol derivatives from propolis could reduce the allergenic symptom of paw edema, inhibit the synthesis of immunoglobulin E (IgE) and immunoglobulin $G_{1}$, reduce the activity of eosinophil peroxidase and reduce the mobility of pulmonary cells. Thus, it is promising that we may be successful in finding new antiinflammatory agent in propolis.

\subsection{Free radical scavenging activity}

Free radicals are oxygen-centered molecules that contain a single electron at the outermost orbit. Although they play an important role in biological processes such as in immunity (intracellular killing of bacteria) and certain redox signaling pathways, their inappropriate expression in terms of level or cellular location can lead to serious cell damage as they can bind to low-density lipoprotein (LDL) and some other compounds including proteins and DNA causing irreversible changes. The bound or modified compounds can be toxic to cells leading to premature or inappropriate cell death, and can cause mutations in the genetic materials transforming normal cells to cancer cells (Campos et al., 2003). Other than cancer, excess free radicals are linked to a diverse array of disorders, such as atherosclerosis, cerebral ischemia, cardiac ischemia, Parkinson's disease, gastrointestinal disturbance and aging (Ames et al., 1993). It has long been challenging to find new free radical scavenging agents. However, with respect to bee products, Choi et al. (2006) reported that A. mellifera propolis from different regions in Korea (Yangpyeong, Boryung, Cheorwon and Yeosu) contained free-radical scavenging activity, but that they differed in their $\mathrm{ED}_{50}$ values between regions. Indeed, propolis from the same bee species collected in Portugal showed the same free radicalscavenging affect (Moreira et al., 2008). Both works also support the idea that natural products from different regions provide an interesting bioactivity at different efficiencies.

Other than propolis, Silva et al. (2005) reported the presence of a free radical scavenging activity in bee pollen from the stingless bee, Melipona subnitida, in Brazil. Analysis of the bee pollen revealed that they were from Mimosa gemmulata, a plant in the Mimosaceae family, and from plants in the Fabaceae family. The efficiency of the free radical scavenging activity obtained mainly depended on the organic solvents used in the extraction process. Ethyl acetate was the most efficient extraction solvent for recovery of this bioactivity, followed by ethanol and hexane, respectively. Active compounds were analyzed to be naringenin, isorhamnetin, D-mannitol, $\beta$-sitosterol, tricetin, selagin and 8-methoxinerbacetin.

\subsection{Antiproliferative activity}

Although cancer research has long been established, cancer is still the leading cause of death and sickness to people worldwide. Due to the high cost of cancer treatment and the 
limitation of recent therapy, including the evolution and spread of resistance to current chemotherapy agents, alternative and complementary medicines are becoming of increasing interest and potential importance, especially those with a different mechanism of action. Indeed, a significant proportion of cancer research has been focused upon finding new anti-cancer agents. With respect to bee products, Awale et al. (2008) reported that the methanolic extract of red propolis in Brazil contained an antiproliferation activity against human pancreatic cancer cells (PANC-1) in tissue culture (in vitro). From this extract, forty-three active chemical compounds were analyzed. Among those, three new compounds, 6)aS,11 aS)-6a-ethoxymedicarpan, 2)-2',4 '-dihydroxyphenyl)--3methyl--6 methoxybenzofuran and 2, 6-dihydroxy-2-[(4-hydroxy-phenyl) methyl]-3-benzo-furanone, were found. In addition, Umthong et al. (2009) reported that the propolis from T. laeviceps in Thailand had an antiproliferative activity against the colon cancer (SW620) cell line in tissue culture. The concentration of the methanolic extract of this propolis showed a linear correlation to the anti-proliferative affect, whereas the water extract revealed a biphasic effect.

Bee pollen has also been reported to have an antiproliferative activity upon cancer cell lines in tissue culture, and this has been linked to the flavonoid composition (Rice-Evans et al., 1997). The antiproliferative activity from A. mellifera bee pollens collected from Cystus incanus L. in Croatia were found to be mediated by phenolic compounds, such as flavonol (pinocembrin), flavanol (quercetin, kaempferol, galangin and isohamnetin), flavones (chrysin) and phenylpropanoid (caffeic acid).

Overall, it is evident that the active chemical compounds and bioactivities depend mainly on the bee species, collecting sites, biogeography and other external factors.

\section{Threats to and conservation of wild bees in Southeast Asia}

\subsection{Deforestation and destruction of nesting sites}

Flint (1994) reported that between 1880 and 1980 Southeast Asia showed an average loss of forest cover area of $0.3 \%$, which was primarily caused from agricultural expansion and commercial logging. Subsequent to 1985, deforestation has remained particulary severe in Southeast Asia (Achard et al., 2002).

Little is known about how deforestation will affect honey bees, especially the giant honey bee. Liow et al. (2001) revealed that the proportion of stingless bees and honey bees (Hymenoptera: Apidae) was very low in oil palm plantation areas and very high in undisturbed areas, which implies that oil palm plantations are not suitable in terms of either fulfilling the preferences of honey bees or the ability to support them. Palm trees do not produce nectar and their dense leaves render them unsuitable for nest building by $A$. dorsata (Oldroyd \& Nanork, 2009).

The removal of nesting trees of $A$. dorsata is of great concern in their conservation (Oldroyd \& Nanork, 2009). Giant honey bees tend to build their nests in aggregations, sometimes with more than 100 colonies on a single tree (Oldroyd et al., 2000). In addition, A. dorsata colonies often migrate long distances, but return to their previous nesting site every year (Koeniger \& Koeniger, 1980). Thus, the felling of major bee trees may cause a significant decline in the $A$. dorsata populations. Although the effects of agricultural landscapes and industrialization have significantly increased in Thailand, deforestation could represent as a main threat to wild honey bee and stingless bee populations and their nesting sites should be protected (Dietemann et al., 2009). 


\subsection{Brood and honey hunting}

Honey hunting is the general term given to the collection of honey from wild honey bee colonies. Traditional honey hunting is an important role in the life of Asian people. They have been hunting wild honey bees for more than 40,000 years (Crane, 1999) and honey bee hunting remains a widespread practice throughout the region (Oldroyd \& Nanork, 2009). The existing method of honey hunting in giant honey bees is the same across Asia. Hunting A. dorsata and A. laboliosa is more ruthless, and often burning the bees with a smoldering torch of tightly-bound brush (Lahjie \& Seibert, 1990). In traditional honey hunting, night time is preferred by many hunters. The smoking is considered crucial to disorientate the bees and so to reduce the number of stings received. After smoking off the bees from the comb, most honey hunters cut down the whole combs destroying all the brood and food stores. A large number of larva and young bees, some hundreds of adult bees and drones are also killed while hunting honey (Tsing, 2003). Many queens must be lost during these harvest methods, and their colonies perish along with them (Oldroyd \& Nanork, 2009). Therefore, these methods of hunting may kill many colonies of A. dorasata within colony aggregations in one night.

\subsection{Honey bee diseases and parasites}

Honey bee colonies can be infected by numerous pathogens (viruses, bacteria, fungi and protozoa), and can be infested by various parasitic insects and mites (Morse \& Nowogrodzki, 1990). Normally, feral honey bee populations are not threatened by the parasites and pathogens with which they have co-evolved (Oldroyd and Nanork, 2009). However, Allen et al. (1990) reported that A. laboriosa populations in Nepal were infected by European foulbrood (Mellisococcus pluton), which they attributed to environmental stress by deforestation. Moreover, A. mellifera colonies have been introduced into many countries in Southeast Asia. Thus, the anthropogenic movement of honey bee populations between countries increasingly exposes wild populations to novel pathogens and parasites that they have no or reduced resistance to the pathogen alone or after subsequent stress (Oldroyd \& Nanork, 2009).

The Tropilaelaps mite is a serious external parasite of the honey bee. Its primary host was subsequently recognized as the giant honeybee, A. dorsata (Laigo \& Morse, 1968) and it has now been reported throughout the entire distribution range of $A$. dorsata (Matheson, 1996). It is also associated with other Asian honey bees, including A. laboriosa, A. cerana and A. florea (Delfinado-Baker et al., 1985).

The greater wax moth, Galleria mellonella, is the most serious pest in honey bee colonies worldwide. Its larvae cause considerable damage to bee colonies by feeding on the wax combs and cells containing broods, honey and pollens. The wax moth larvae also destroy the comb structure by forming tunnels inside the comb (Jyothi et al., 1990). Furthermore, Tingek et al. (2004) reported that a Conopid fly, Physocephala parralleliventris Kröber (Diptera: Conopidae) parasitizes A. dorsata, A. cerana, and A. koschevnikovi in Borneo. This fly grasps foraging bees in flight and deposits a larva on the integument. Then, the larva penetrates the bee cuticle and consumes the bee from the inside.

\subsection{Pesticides}

Some commercial fruit orchards, particularly longan (Dimocarpus longan), litchi (Litchi chinensis) and citrus are major nectar producers which are highly attractive to honey bees 
(Crane et al., 1984). Commercial sun flower (Helianthus annuus) plantations are one of the most important sources of pollen and nectar for bees in Thailand. However, these commercial crops are regularly sprayed with insecticides, especially in the flowering period. Oil palm (Elaeis spp.) orchards are also regularly exposed to insecticides, and this may contribute to the observed low number of honey bees within oil palm crops (Oldroyd \& Nanork, 2009). Colonies of all bee species may lose field bees when foraging on crops that are exposed to insecticides. The regulation of pesticide use is lax in some Southeast Asia countries, and can increase the possibility of honey bees exposure to pesticides (Oldroyd \& Wongsiri, 2006).

\subsection{Impact of climate change}

Climate influences flower development and nectar and pollen production, which are directly linked with the colonies' foraging activity and development (Winston, 1987). A major effect of climate change on honey bees stems from changes in the distribution of the flower species (Thuiller et al., 2005) on which the bees depend for food. Rain can impact on honey harvesting. For example, when acacia (Acacia spp.) flowers are washed by rain, they are no longer attractive to honey bees as it dilutes their nectar too much (Conte \& Navajas, 2008). Likewise, an overly dry climate can reduce the production of flower nectar for honey bees to harvest, since many plant flowers produce no nectar when the weather is too dry, which makes harvesting by bees a largely hypothetical matter. In these situations, honey bees can die of starvation.

\section{Conclusion}

In Southeast Asia, the bee diversity is very high, especially for honey bees (Apis spp.). In Thailand, there are four native honey bees; A. cerana, A. florea, A. dorsata and A. andreniformis, plus the anthropogenically imported A. mellifera. Other than Apis spp., stingless bees can produce honey as well. In Thailand, there are more than 50 species of stingless bees, of which the most common is T. laeviceps. Besides the biology, diversity and ecology of the bees, variation, both morphometric and genetic variations have been evaluated. In addition, although the gender of bees can be distinguished easily by their morphology, geometric morphometric analysis of their wings alone could successfully distinguish the genders. Bees are classified as eusocial insects since there are three distinct castes within a hive; that is the queen, drones and workers. Not only are bees are very useful as pollinators, but their bee products, especially honey, are economically important. Other than being consumed as food, bee products, especially honey, propolis and bee pollens, have long been used in traditional medicine. They provide many bioactivities, such as antimicrobial, antiinflammatory, free radical scavenging and antiproliferation activities amongst others. Although they are important in agriculture, at present, it is obvious that there is a decrease in the number of hives of these bees. This may be due to a combination of deforestation, hunting, diseases, pesticide and other factors. Thus, it is very important to consider the conservation of bees and promote the bee management in each country.

\section{Acknowledgments}

We thank the Thailand Research Fund (grant \# RMU5180042), the National Research Council of Thailand, the Asahi Glass Foundation, the Thai Government Stimulus Package 2 
(TKK2555), under the Project for Establishment of Comprehensive Center for Innovative Food, Health Products and Agriculture, the Ratchadapisek Somphot Endowment Fund (AG001B), and the Higher Education Research Promotion and National Research University Project of Thailand, Office of the Higher Education Commission for financial support. We also, thank Dr. Robert Butcher for chapter preparation.

\section{References}

Achard, F.; Eva, H.D.; Stibig, H.-J.; Mayaux, P.; Gallego, J.; Richards, T. \& Malingreau, J.-P. (2002). Determination of Deforestation Rates of the World's Humid Tropical Forests. Science, Vol.297, No.5583, (August 2002), pp. 999-1002

Allen, M.F.; Ball, B.V. \& Underwood, B.A. (1990). An Isolation of Melissococcus pluton From Apis laboriosa. Journal of Invertebrate Pathology, Vol.55, pp. 439-440

Ames, B.N.; Shigenaga, M.K. \& Hagen, T.M. (1993). Oxidants, Antioxidants, and the Degenerative Diseases of Aging. Proceedings of the National Academy of Sciences of the United States of America, Vol.90, No.17, pp. 7915-7922

Appanah, S. (1993). Mass Flowering of Dipterocarp Forests in the Aseasonal Tropics. Journal of Biosciences, Vol.18, No.4, (December 1993), pp. 457-474

Arias, M.C.; Brito, R.M.; Francisco, F.D.O.; Moretto, G.; De Oliveira, F.F.; Silvestre, D. \& Sheppard, W.S. (2006). Molecular Markers as a Tool for Population and Evolutionary Studies of Stingless Bees. Apidologies, Vol.37, No.2, (March-April 2006), pp. 259-274, ISSN 0044-8435

Arias, M.C. \& Sheppard, W.S. (2005) Phylogenetic Relationships of Honey Bees (Hymenoptera: Apinae: Apini) Inferred from Nuclear and Mitochondrial DNA Sequence Data. Molecular Phylogenetics and Evolution, Vol.37, No.1, (October 2005), pp. 25-35

Awale, S.; Li, F.; Onozuka, H.; Esumi, H.; Tezuka, Y. \& Kadota, S. (2008). Constituents of Brazilian Red Propolis and Their Preferential Cytotoxic Activity Against Human Pancreatic PANC-1 Cancer Cell Line in Nutrient-deprived Condition. Bioorganic and Medicinal Chemistry, Vol.16, (October 2007), pp. 181-189

Banerjee, B. (2006). Topical Honey Application vs. Acyclovir for the Treatment of Recurrent Herpes Simplex Lesions. Medical Science Monitor, Vol.12, No.9, p. LE18

Boorn, K.L.; Khor, Y.-Y.; Sweetman, E.; Tan, F.; Heard, T.A. \& Hammer, K.A. (2010). Antimicrobial Activity of Honey From the Stingless Bee Trigona carbonaria Determined by Agar Well Diffusion, Agar Dilution, Broth Microdilution and Timekill Methodology. Journal of Applied Microbiology, Vol.108, No.5, (October 2009), pp. 1534-1543, ISSN 1364-5072

Campos, M.G.; Webby, R.F.; Markham, K.R.; Mitchell, K.A. \& Da Cunha, A.P. (2003). Ageinduced Diminution of Free Radical Scavenging Capacity in Bee Pollens and the Contribution of Constituent Flavonoids. Journal of Agricultural and Food Chemistry, Vol.51, pp. 742-745

Castaldo, S. \& Capasso, F. (2002). Propolis, an Old Remedy Used in Modern Medicine. Fitoterapia, Vol.73, pp. S1-6

Chaiyawong, T.; Deowanish, S.; Wongsiri, S.; Sylvester, H.A.; Rinderer, T. \& De Guzman, L. (2004). Multivariate Morphometric Study of Apis florea in Thailand. Journal of Apicultural Research, Vol.43, No.3, (October 2004), pp. 123-127, ISSN 0021-8839 
Choi, Y.M.; Noh, D.O.; Cho, S.Y.; Suh, H.J.; Kim, K.M. \& Kim, J.M. (2006). Antioxidant and Antimicrobial Activities of Propolis from Several Regions of Korea. Food Science and Technology, Vol.39, pp. 756-761

Conte, Y.L. \& Navajas, M. (2008). Climate Change: Impact on Honey Bee Populations and Diseases. Revue Scientifique Et Technique International Office of Epizootics, Vol.27, No.2, (August 2008), pp. 499-510, ISSN 0253-1933

Corlett, R.T. (2001). Pollination in a Degraded Tropical Landscape: a Hong Kong Case Study. Journal of Tropical Ecology, Vol.17, No.1, (January 2001), pp. 155-161

Cortopassi-Laurino, M.; Imperatriz-Fonseca, V.L.; Roubik, D.W.; Dollin, A.; Heard, T.; Aguilar, I.; Venturieri, G.C.; Eardley, C.\& Nogueira-Neto, P. (2006). Global Meliponiculture: Challenges and Opportunities. Apidologies, Vol.37, No.2, (MarchApril 2006), pp. 275-292, ISSN 0044-8435

Crane, E., Walker, P. \& Day, R. (1984). Honey Plants of the World, International Bee Research Association, London, UK

Crane, E. (1990). Bees and Beekeeping: Science, Practice and World Resources, Heinemann Newnes, ISBN 0-434-90271-3, Oxford, UK

Crane, E.; Van Luyen, V.; Mulder, V. \& Ta, T.C. (1993). Traditional Management System for Apis dorsata in Submerged Forests in Southern Vietnam and Central Kalimantan. Bee World, Vol.74, No.1, pp. 27-40, ISSN 0005-772X

Crane, E. (1999). The World History of Beekeeping and Honey Hunting. Duckworth, London

Cushnie, T.P.T. \& Lamb, A.J. (2005). Detection of Galangin-induced Cytoplasmic Membrane Damage in Staphylococcus aureus by Measuring Potassium Loss. Journal of Ethnopharmacology, Vol.101, pp.243-248

Dayanandan, S.; Attygalla, D.N.C.; Abeygunasekera, A.W.W.L.; Gunatilleke, I.A.U.N. \& Gunatilleke, C.V.S. (1990). Phenology and Floral Morphology in Relation to Pollination of Some Sri Lankan Dipterocarps. In: Reproductive Ecology of Tropical Forest Plants, K.S. Bawa \& M. Hadley, (Ed.), 103-134, Parthenon, Carnforth, UK

Delfinado-Baker, M.; Underwood, B.A. \& Baker, E.W. (1985). The Occurrence of Tropilaelaps Mites in Brood Nests of Apis dorsata and A. laboriosa in Nepal, with Descriptions of the Nymphal Stages. American Bee Journal, Vol.125, No.10, pp. 703-706, ISSN 00027626

Deowanish, S.; Nakamura, J.; Matsuka, M. \& Kimura, K. (1996). MtDNA Variation Among Subspecies of Apis cerana Using Restriction Fragment Length Polymorphism. Apidologie, Vol.27, No.5, pp. 407-413, ISSN 0044-8435

Dornhaus, A.; Klugl, F.; Oechslein, C.; Puppe, F. \& Chittka, L. (2006). Benefits of Recruitment in Honey Bees: Effects of Ecology and Colony Size in an Individual Based Model. Behavioral Ecology, Vol.17, No.3, (January 2006), pp. 336-344

Dietemann, V.; Pirk, C.W.W. \& Crewe, R. (2009). Is There a Need for Conservation of Honey Bees in Africa. Apidologies, Vol.40, No.3, (May-June 2009), pp. 285-295

Engels, W. (1999). The Taxonomy of Recent and Fossil Honey Bees (Hymenoptera: Apidae; Apis). Journal of Hymenoptera Research, Vol.8, No.2, pp. 165-196, ISSN 1070-9428

Erukhimovitch, V.; Talyshinsky, M.; Souprun, Y. \& Huleihe, M. (2006). Spectroscopic Investigation of Herpes Simplex Viruses Infected Cells and Their Response to Antiviral Therapy. Journal of Molecular Structure, Vol.792-793, pp. 99-103 
Flint, E.P. (1994). Changes in Land Use in South and Southeast Asia from 1880 to 1980: A Data Base Prepared as Part of a Coordinated Research Program on Carbon Fluxes in the Tropics. Chemosphere, Vol.29, No.5, (September 1994), pp. 1015-1062

Gould, J.L. \& Gould, C.G. (1988). The Honey Bee, Scientific American Library, ISBN 0-71675023-6, New York, USA

Gullan, P.J. \& Cranston, P.S. (2000). The Insects: An Outline of Entomology, (2nd edition), MPG Books Ltd, ISBN 0-632-05343-7, Cornwall

Hepburn, H.R. \& Hepburn, C. (2005). Bibliography of Apis florea. Apidologie, Vol.36, No.3, (July-September 2005), pp. 377-378

Hu, F.; Hepburn, H.R.; Li, Y.; Chen, M.; Radloff, S.E. \& Dava, S. (2005). Effects of Ethanol and Water Extracts of Propolis (Bee Glue) on Acute Inflammatory Animal Models. Journal of Ethnopharmacology, Vol.100, Nov.3, pp. 276-283

Itioka, T.; Inoue, T.; Kaliang, H.; Kato, M.; Nagamitsu, T.; Momose, K.; Sakai, S.; Yumoto, T.; Mohamad, S.U.; Hamid, A.A. \& Yamane, S. (2001). Six-year Population Fluctuation of Giant Honey Bee Apis dorsata (Hymenoptera: Apidae) in Tropical Lowland Dipterocarp Forest in Sarawak. Annals of the Entomological Society of America, Vol.94, No.4, pp. 545-549

Jirakanwisal, K. (2010). Antimicrobial Activity on Methicillin-resistant Staphylococcus aureus by Trigona laeviceps Honey Extract. Bachelor's Senior Project, Department of Biology, Faculty of Science, Chulalongkorn University

Johnson, S.D. \& Steiner, K.E. (2000). Generalization Versus Specialization in Plant Pollination Systems. Trends in Ecology and Evolution, Vol.15, (April 2000), pp. 140143

Jyothi, J.V.A.; Reddy, M.S. \& Reddy, C.C. (1990). Incidence of Infestation of Greater Wax Moth in Apis dorsata Colonies, In: Social Insects: An Indian Perspective, G.K. Veeresh, A.R.V. Kumar \& T. Shivashankar, (Ed.), 219-223, IUSSI, Indian Chapter, Bangalore

Katircioglu, H. \& Mercan, N. (2006). Antimicrobial Activity and Chemical Compositions of Turkish Propolis From Different Region. African Journal of Biotechnology, Vol.11, pp. 1151-1153

Kirchner, W.H.; Dreller, C.; Grasser, A. \& Baidya, D. (1996). The Silent Dances of Himalayan Honey Bee, Apis laboriosa. Apidologie, Vol.27, No.5, pp. 331-339, ISSN 0044-8435

Klakasikorn, A.; Wongsiri, S.; Deowanish, S. \& Duangphakdee, O. (2005). New Record of Stingless Bees (Meliponini: Trigona) in Thailand. The Natural History Journal of Chulalongkorn University, Vol.5, No.1, (May 2005), pp. 1-7, ISSN 1513-9700

Koeniger, N. \& Koeniger, G. (1980). Observations and Experiments on Migration and Dance Communication of Apis dorsata in Sri Lanka. Journal of Apicultural Research, Vol.19, No.1, pp. 21-34, ISSN 0021-8839

Koeniger, N.; Koeniger, G.; Tingek, S.; Mardan, M. \& Rinderer, T.E. (1988). Reproductive Isolation by Different Time of Drone Flight Between Apis cerana Fabricius, 1793 and Apis vechti (Maa, 1953). Apidologie, Vol.19, No.1, pp. 103-106

Kujumgiev, A.; Tsvetkova, I.; Serkedjieva, Y.; Bankova, V.; Christov, R. \& Popov, S. (1999). Antibacterial, Antifungal and Antiviral Activity of Propolis of Different Geographic Origin. Journal of Ethnopharmacology, Vol.64, No.3, pp. 235-240

Kubo, T.; Sasaki, M.; Nakamura, J.; Sasagawa, H.; Ohashi, K.; Takeuchi, H. \& Natori, S. (1996). Change in the Expression of Hypopharyngeal Gland Proteins of the 
Workers Honey Bees (Apis mellifera L.) with Age and/or Role. Journal of Biochemistry, Vol.119, pp.291-295

Kwakman, P.H.S.; Den Akker, J.P.C.V.; Guclu, A.; Aslami, H.; Binnekade, J.M.; De Boer, L.; Boszhard, L.; Paulus, F.; Middelhoek, P.; Te Velde, A.A.; Vandenbroucke-Grauls, C.M.J.E.; Schultz, M.J. \& Zaat, S.A.J. (2008). Medical-grade Honey Kills Antibioticresistant Bacteria In Vitro and Eradicates Skin Colonization. Clinical Infectious Diseases, Vol.46, No.11, (June 2008), pp. 1677-1682

Kwakman, P.H.S.; De Boer, L.; Ruyter-Spira, C.P.; Creemers-Molenaar, T.; Helsper, J.P.F.G.; Vandenbroucke, C.M.J.E.; Zaat, S.A.J. \& Te Velde, A.A. (2011). Medical-grade Honey Enriched with Antimicrobial Peptides Has Enhanced Activity Against Antibiotic-resistant Pathogens. European Journal of Clinical Microbiology and Infectious Diseases, Vol.30, No.2, (October 2010), pp. 251-257

Lahjie, A.M. \& Seibert, B. (1990). Honey Gathering by People in the Interior of East Kalimantan. Bee World, Vol.71, No.3, pp. 153-157, ISSN 0005-772X

Laigo, F.M. \& Morse, R.A. (1968). The Mite Tropilaelaps clareae in Apis dorsata Colonies in the Philippines. Bee World, Vol.49, pp. 116-118, ISSN 0005-772X

Limbipichai, K. (1990). Morphometric Studies on the Eastern Honey Bee (Apis cerana Fabricius) in Thailand and the Malaysian Peninsula. Master's Thesis, Department of Biology, Graduate School, Chulalongkorn University, ISBN 9745779954

Lin, S.M.; Molan, P.C. \& Cursons, R.T. (2011). The Controlled In Vitro Susceptibility of Gastrointestinal Pathogens to the Antibacterial Effect of Manuka Honey. European Journal of Clinical Microbiology and Infectious Diseases, Vol. 30, No.4, (December 2010), pp. 569-574

Liow, L.H.; Sodhi, N.S. \& Elmqvist, T. (2001). Bee Diversity Along a Disturbance Gradient in Tropical Lowland Forests of South-east Asia. Journal of Applied Ecology, Vol.38, No.1 (Febuary 2001), pp. 180-192, Available from http://www.jstor.org/stable/2655743

Lo, N.; Gloag, R.S.; Anderson, D.L. \& Oldroyd, B.P. (2010). A Molecular Phylogeny of the Genus Apis Suggests that the Giant Honey Bee of the Philippines, A. breviligula Maa, and the Plains Honey Bee of Southern India, A. indica Fabricius, are Valid Species. Systematic Entomology, Vol.35, No.2, (December 2009), pp. 226-233

Maeda, Y.; Loughrey, A.; Philip Earle, J.S.; Cherie Millar, B.; Rao, J.R.; Kearns, A.; McConville, O.; Goldsmith, C.E.; Rooney, P.J.; Dooley, J.S.G.; Lowery, C.J.; Snelling, W.J.; McMahon, A.; McDowell, D. \& Moore, J.E. (2008). Antibacterial Activity of Honey Against Community-associated Methicillin-resistant Staphylococcus aureus (CA-MRSA). Complementary Therapies in Clinical Practice, Vol.14, pp. 77-82

Marcucci, M.C.; Ferreres, F.; Garc a-Viguera, C.; Bankova, V.S.; De Castro, S.L.; Dantas, A.P.; Valente, P.H.M. \& Paulino, N. (2001). Phenolic Compounds From Brazilian Propolis with Pharmacological Activities. Journal of Ethnopharmacology, Vol.74, pp. 105-112

Matheson, A. (1996). World Bee Health Update 1996. Bee World, Vol.77, No.1, pp. 45-51, ISSN: 0005-772X

Medeiros, K.C.P.; Figueiredo, C.A.V.; Figueredo, T.B.; Freire, K.R.L.; Santos, F.A.R.;Alcantara-Neves, N.M.; Silva, T.M.S. \& Piuvezam, M.R. (2008). Anti-allergic Effect of Bee Pollen Phenolic Extract and Myricetin in Ovalbumin-sensitized Mice. Journal of Ethnopharmacology, Vol.119, pp. 41-46

Michener, C.D. (2000). The Bees of the World, The John Hopkins University Press, London 
Michener, C.D. (2007). The Bees of the World, (2nd edition), The Johns Hopkins University Press, ISBN 978-0-8018-8573-0, Maryland, USA

Mirzoeva, O.K.; Grishanin, R.N. \& Calder, P.C. (1997). Antimicrobial Action of Propolis and Some of Its Components: The Effects on Growth, Membrane Potential and Mobility of Bacteria. Microbiological Research, Vol.152, No.3, pp. 239-246

Mogga, J. \& Ruttner, F. (1988). Apis florea in Africa: Source of the Founder Population. Bee World, Vol.69, pp. 100-103, ISSN 0005-772X

Momose, K., Yumoto, T., Nagamitsu, T., Kato, M., Nagamasu, H., Sakai, S., Harrison, R.D., Itioka, T., Hamid, A.A. \& Inoue, T. (1998). Pollination Biology in a Lowland Dipterocarp Forest in Sarawak, Malaysia. I. Characteristics of the Plant-pollinator Community in a Lowland Dipterocarp Forest. American Journal of Botany, Vol.85, No.10, pp. 1477-1501, ISSN 1537-2197

Moreira, L.; Dias, L.G.; Pereira, J.A. \& Estevinho, L. (2008). Antioxidant Properties, Total Phenols and Pollen Analysis of Propolis Samples From Portugal. Food and Chemical Toxicology, Vol.46, pp. 3482-3485

Morse, R.A. \& Laigo, F.M. (1969). Apis dorsata in the Philippines. Philippines Association of Entomologists, Laguna

Morse, R.A. \& Nowogrodzki, R. (1990). Honey Bee Pests, Predators and Diseases, Cornell University Press, ISBN 0801424062, Ithaca, USA

Nanork, P. (2001). Mitochondrial DNA Variability of Dwarf Honey Bee Apis florea Fabricius, 1787 in Thailand Using PCR-RFLP Technique. Master's Thesis, Department of Biology, Graduate School, Chulalongkorn University, ISBN 974-03-0309-9

Oldroyd, B.P.; Clifton, M.J.; Wongsiri, S.; Rinderer, T.E.; Sylvester, H.A. \& Crozier, R.A. (1997). Polyandry in the Genus Apis, Particularly in Apis andreniformis. Behavioral Ecology and Sociobiology, Vol.40, No.1, (January 1997), pp. 17-26, ISSN 1432-0762

Oldroyd, B.P.; Osborne, K.E. \& Mardan, M. (2000). Colony Relatedness in Aggregations of Apis dorsata Fabricius (Hymenoptera, Apidae). Insectes Sociaux, Vol.47, No.1, pp. 9495

Oldroyd, B.P. \& Wongsiri, S. (2006). Asian Honey Bees: Biology, Conservation and Human Interactions, Harvard University Press, ISBN 0-674-02194-0, Massachusetts, USA

Oldroyd, B.P. \& Nanork, P. (2009). Conservation of Asian Honey Bees. Apidologie, Vol.40, No. 3, (May-June 2009), pp. 296-312

Paar, J.; Oldroyd, B.P. \& Kasberger, G. (2000). Giant Honey Bees Return to Their Nesting Sites. Nature, Vol.206, (August 2000), pp. 475

Paar, J.; Oldroyd, B.P.; Huettinger, E. \& Kastberger, G. (2004). Genetic Structure of an Apis dorsata Populations: The Significance of Migration and Colony Aggregation. Journal of Heredity, Vol.95, (March 2004), pp. 119-126

Paulino, N.; Dantas, A.P.; Bankova, V.; Longhi, D.T.; Scremin, A.; De Castro, S.L. \& Calixto, J.B. (2003). Bulgarian Propolis Induces Analgesic and Anti-inflammatory Effects in Mice and Inhibits In Vitro Contraction of Airway Smooth Muscle. Journal of Pharmacological Sciences, Vol.93, pp. 307-313

Peter, J.; Queller, D.C.; Imperatriz-Fonseca, V.L.; Roubik, D.W. \& Strassmann, J.E. (1999). Mate Number, Kin Selection and Social Conflicts in Stingless Bees and Honey Bees. Proceedings of the Royal Society London B, Vol.266, pp. 379-384, ISSN 1471-2954 
Quiroga, E.N.; Sampietro, D.A.; Soberon, J.R.; Sgariglia, M.A. \& Vattuone, M.A. (2006). Propolis From the Northwest of Argentina as a Source of Antifungal Principles. Journal of Applied Microbiology, Vol.101, pp. 103-110

Radloff, S.E.; Hepburn, H.R. \& Engle, M.S. (2011). The Asian Species of Apis, In: Honey bees of Asia, H.R. Hepburn \& S.E. Radloff, (Ed.), 1-22, Springer-Verlag, ISBN 978-3-64216421-7, Berlin, Germany

Raffiudin, R. \& Crozier, R.H. (2007). Phylogenetic Analysis of Honey Bee Behavioral Evolution. Molecular Phylogenetics and Evolution, Vol.43, (May 2007), pp. 543-552

Rahman, A. \& Rahman, S. (2000). Effect of Honey Bee (Apis cerana indica) Pollination on Seed Set and Yield of Buckwheat (Fagopyrum esculentum). Indian Journal of Agricultural Sciences, Vol.70, No.3, pp. 168-169, ISSN 0019-5022

Rattanawannee, A.; Chanchao, C. \& Wongsiri, S. (2007). Morphometric and Genetic Variation of Small Dwarf Honey Bees Apis andreniformis Smith, 1858 in Thailand. Insect Science, Vol.14, No.6, (December 2007), pp. 451-460, ISSN 1744-7917

Rattanawannee, A.; Chanchao, C. \& Wongsiri, S. (2010). Gender and Species Identification of Four Native Honey Bees (Apidae: Apis) in Thailand Based on Wing Morphometric Analysis. Annals of the Entomological Society of America, Vol.103, No.6, (November 2010), pp. 965-970, ISSN 0013-8746

Rice-Evans, C.A.; Miller, N.J. \& Paganga, G. (1997). Antioxidant Properties of PhenolicCompounds. Trends in Plant Science, Vol.2, pp. 152-159

Richards, A.J. (2001). Does Low Biodiversity Resulting From Modern Agricultural Practice Affect Crop Pollination and Yield? Annals of Botany, Vol.88, pp. 165-172

Rinderer, T.; Oldroyd, B.; Lekprayoon, C.; Wongsiri, S.; Boonthai, C. \& Thapa, R. (1994). Extended Survival of the Parasitic Honey Bee Mite Tropilaelaps clareae on Adult Workers of Apis mellifera and Apis dorsata. Journal of Apicultural Research, Vol.33, No.3, (September 1994), pp. 171-173, ISSN 0021-8839

Rinderer, T.E.; Oldroyd, B.P.; Wongsiri, S.; Sylvester, H.A.; De Guzman, L.I.; Stelzer, J.A. \& Giggio, R.M. (1995). A Morphological Comparison of the Dwarf Honey Bees of South-eastern Thailand and Palawan, Philippines. Apidologies, Vol. 26, No.5, pp. 387-394

Rinderer, T.E.; Wongsiri, S.; Kuang, B.; Liu, J.; Oldroyd, B.P.; Sylvester, H.A.; De Guzman, L.I.; Kuang, H.; Dong, X. \& Zhai, W. (1996). Comparative Nest Architecture of the Dwarf Honey Bees. Journal of Apicultural Research, Vol.35, No.1, (January 1996), pp. 19-26, ISSN 0021-8839

Roubik, D.W. (1989). Ecology and Natural History of Tropical Bees, (1 ${ }^{\text {st }}$ edition), Cambridge University Press, ISBN 0-521-26236-4, Cambridge, UK

Roubik, D.W. (2006). Stingless Bee Nesting Biology. Apidologies, Vol.37, No.2, (March-April 2006), pp. 124-143, ISSN 0044-8435

Ruttner, F. (1988). Biogeography and Taxonomy of Honey Bees, Springer-Verlag Berlin, ISBN 0387-17781-7, Heidelberg, Germany

Saric, A.; Balog, T.; Sobocanec, S.; Kusic, B.; Sverko, V.; Rusak, G.; Likic, S.; Bubalo, D.; Pinto, B.; Reali, D. \& Marotti, T. (2009). Antioxidant Effects of Flavonoids from Croatian Cystus incanus L. Rich Bee Pollen. Food and Chemical Toxicology, Vol.47, pp. 547-554

Sihanuntavong, D.; Sittipraneed, S. \& Klinbunga, S. (1999). Mitochondrial DNA Diversity and Population Structure of the Honey Bee (Apis cerana) in Thailand. Journal of Apicultural Research, Vol.38, No.3-4, pp. 211-219, ISSN 00218839 
Silva, T.M.S.; Camara, C.A.; Lins, A.C.S.; Barbosa-Filho, J.M.; Da Silva, E.M.S.; Freitas, B.M.\& Santos, F.A.R. (2005). Chemical Composition and Free Radical Scavenging Activity of Pollen Load From Stingless Bee Milipona subnitida Ducke. Journal of Food Composition and Analysis, Vol.19, pp. 507-511

Slessor, K.N.; Kaminski, L.A.; King, G.G.S.; Borden, J.H. \& Winston, M.L. (1988). Semiochemical Basis of the Retinue Response to Queen Honey Bees. Nature, Vol.332, (March 1988), pp. 354-356

Songram, O.; Sittipraneed, S. \& Klinbunga, S. (2006). Mitochondrial DNA Diversity and Genetic Differentiation of the Honey Bee (Apis cerana) in Thailand. Biochemical Genetics, Vol.44, No.5-6, (June 2006), pp. 256-269

Tahmasebi, G.; Ebadi, R.; Tajabadi, N.; Akhoundi, M. \& Faraji, S. (2002). The Effects of Geographical and Climatic Conditions on the Morphological Variation and Seperation of Iranian Small Honey Bee (Apis florea F.) Populations. Journal of Science and Technology of Agriculture and Natural Resources, Vol.6, pp. 169-176, ISSN 10287655

Takaisi, N.B. \& Schilcher, H. (1994). Electron Microscopy and Microcalorimetric Investigations of the Possible Mechanism of the Antibacterial Action of a Defined Propole Provenance. Planta Medica, Vol.60, pp. 222-227

Tan, N.Q. (2007). Biology of Apis dorsata in Vietnam. Apidologie, Vol.38, No.3, (May-June 2007), pp. 221-229

Tan, N.Q.; Chinh, P.H.; Thai, P.H. \& Mulder, V. (1997). Rafter Beekeeping with Apis dorsata: Some Factors Affecting the Occupation of Rafters by Bees. Journal of Apicultural Research, Vol.36, No.1, pp. 49-54

Thuiller, W.; Lavorel, S.; Araujo, M.B.; Sykes, M.T. \& Prentice, I.C. (2005). Climate Change Threats to Plant Diversity in Europe. Proceeding of the National Academy of Science of the United State of America, Vol.102, No.23, pp. 8245-8250, ISSN 0027-8424

Tingek, S.; Koeniger, G.; Koeniger, N. \& Gries, M. (2004). Physocephala paralliventris Kröber (Conopidae), a Parasitic Fly of Three Apis Species in Northern Borneo, Proceeding of the $7^{\text {th }}$ Asian Apicultural Association Conference and $10^{\text {th }}$ Beenet Symposia and Technofora, pp. 364-365, ISBN 971-547 215-X, Los Baños, Philippines, February 2327,2004

Tsing, A.L. (2003). Cultivating the Wild: Honey-hunting and Forest Management in Southeast Kalimantan, In: Culture and the Question of Rights: Forests Coasts and Seas in Southeast Asia, C. Zerner, (Ed.), 24-55, Duke University Press, ISBN 978-082-232813-1, Durham, USA

Umthong, S.; Puthong, S. \& Chanchao, C. (2009). Trigona laeviceps Propolis from Thailand: Antimicrobial, Antiproliferative and Cytotoxic Activities. The American Journal of Chinese Medicine, Vol.37, No.5, pp. 855-865

Underwood, B.A. (1990). Time of Drone Flight in Apis laboriosa Smith in Nepal. Apidologie, Vol.21, No.6, pp. 501-504

Wattanachaiyingcharoen, W.; Oldroyd, B.P.; Wongsiri, S.; Palmer, K. \& Paar, J. (2003). A Scientific Note on the Mating Frequency of Apis dorsata. Apidologie, Vol.34, No.1, (January-February, 2003), pp. 85-86

Wilson, E.O. (1971). The Insect Societies, Harvard University Press, Massachusetts, USA

Winston, M.L. (1987). The Biology of the Honey Bee, Harvard University Press, ISBN 0-67407409-2, Massachusetts, USA 
Wongsiri, S.; Lai, Y. \& Liu, Z. (1986). Beekeeping in Guangdong Province of China and Some Observation on the Chinese Honey Bee Apis cerana cerana and the European Honey Bee Apis mellifera ligustica. American Bee Journal, Vol.126, pp. 748-752

Wongsiri, S.; Lekprayoon, C.; Thapa, R.; Thirakupt, K.; Rinderer, T.E.; Sylvester, H.A.; Oldroyd, B.P. \& Booncham, U. (1996). Comparative Biology of Apis andreniformis and Apis florea in Thailand. Bee World, Vol.77, No.4, pp. 23-35, ISSN 0005-772X

Wu, Y.-R. \& Kuang, B. (1987). Two Species of Small Honey Bee: A Study of the Genus Micrapis. Bee World, Vol.68, No.3, pp. 153-155, ISSN 0005-772X 


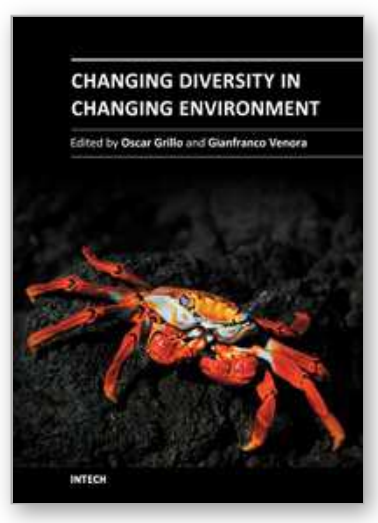

\author{
Changing Diversity in Changing Environment \\ Edited by PhD. Oscar Grillo
}

ISBN 978-953-307-796-3

Hard cover, 392 pages

Publisher InTech

Published online 14, November, 2011

Published in print edition November, 2011

As everybody knows, the dynamic interactions between biotic and abiotic factors, as well as the anthropic ones, considerably affect global climate changes and consequently biology, ecology and distribution of life forms of our planet. These important natural events affect all ecosystems, causing important changes on biodiversity. Systematic and phylogenetic studies, biogeographic distribution analysis and evaluations of diversity richness are focal topics of this book written by international experts, some even considering economical effects and future perspectives on the managing and conservation plans.

\title{
How to reference
}

In order to correctly reference this scholarly work, feel free to copy and paste the following:

Atsalek Rattanawannee and Chanpen Chanchao (2011). Bee Diversity in Thailand and the Applications of Bee Products, Changing Diversity in Changing Environment, PhD. Oscar Grillo (Ed.), ISBN: 978-953-307-796-3, InTech, Available from: http://www.intechopen.com/books/changing-diversity-in-changing-environment/beediversity-in-thailand-and-the-applications-of-bee-products

\section{INTECH}

open science | open minds

\section{InTech Europe}

University Campus STeP Ri

Slavka Krautzeka 83/A

51000 Rijeka, Croatia

Phone: +385 (51) 770447

Fax: +385 (51) 686166

www.intechopen.com

\section{InTech China}

Unit 405, Office Block, Hotel Equatorial Shanghai

No.65, Yan An Road (West), Shanghai, 200040, China

中国上海市延安西路65号上海国际贵都大饭店办公楼 405 单元

Phone: +86-21-62489820

Fax: +86-21-62489821 
(C) 2011 The Author(s). Licensee IntechOpen. This is an open access article distributed under the terms of the Creative Commons Attribution 3.0 License, which permits unrestricted use, distribution, and reproduction in any medium, provided the original work is properly cited. 